\title{
Ground-Water Development and the Effects on Ground-Water Levels and Water Quality in the Town of Atherton, San Mateo County, California
}

By LOREN F. METZGER and JOHN L. FIO

\section{U.S. GEOLOGICAL SURVEY}

Water-Resources Investigations Report 97-4033

Prepared in cooperation with the

TOWN OF ATHERTON, CALIFORNIA

$\frac{0}{n}$

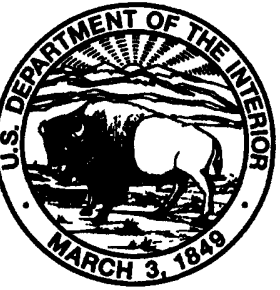




\title{
U.S. DEPARTMENT OF THE INTERIOR BRUCE BABBITT, Secretary
}

\author{
U.S. GEOLOGICAL SURVEY
}

Gordon P. Eaton, Director

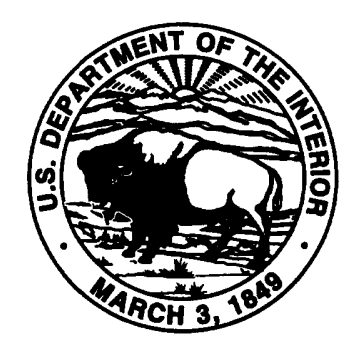

The use of firm, trade, and brand names in this report is for identification purposes only and does not constitute endorsement by the U.S. Geological Survey.

For additional information write to:

\section{District Chief}

U.S. Geological Survey

Placer Hall, Suite 2012

$6000 \mathrm{~J}$ Street

Sacramento, CA 95819-6129
Copies of this report can be purchased from:

U.S. Geological Survey

Information Services

Box 25286

Federal Center

Denver, CO 80225 


\section{CONTENTS}

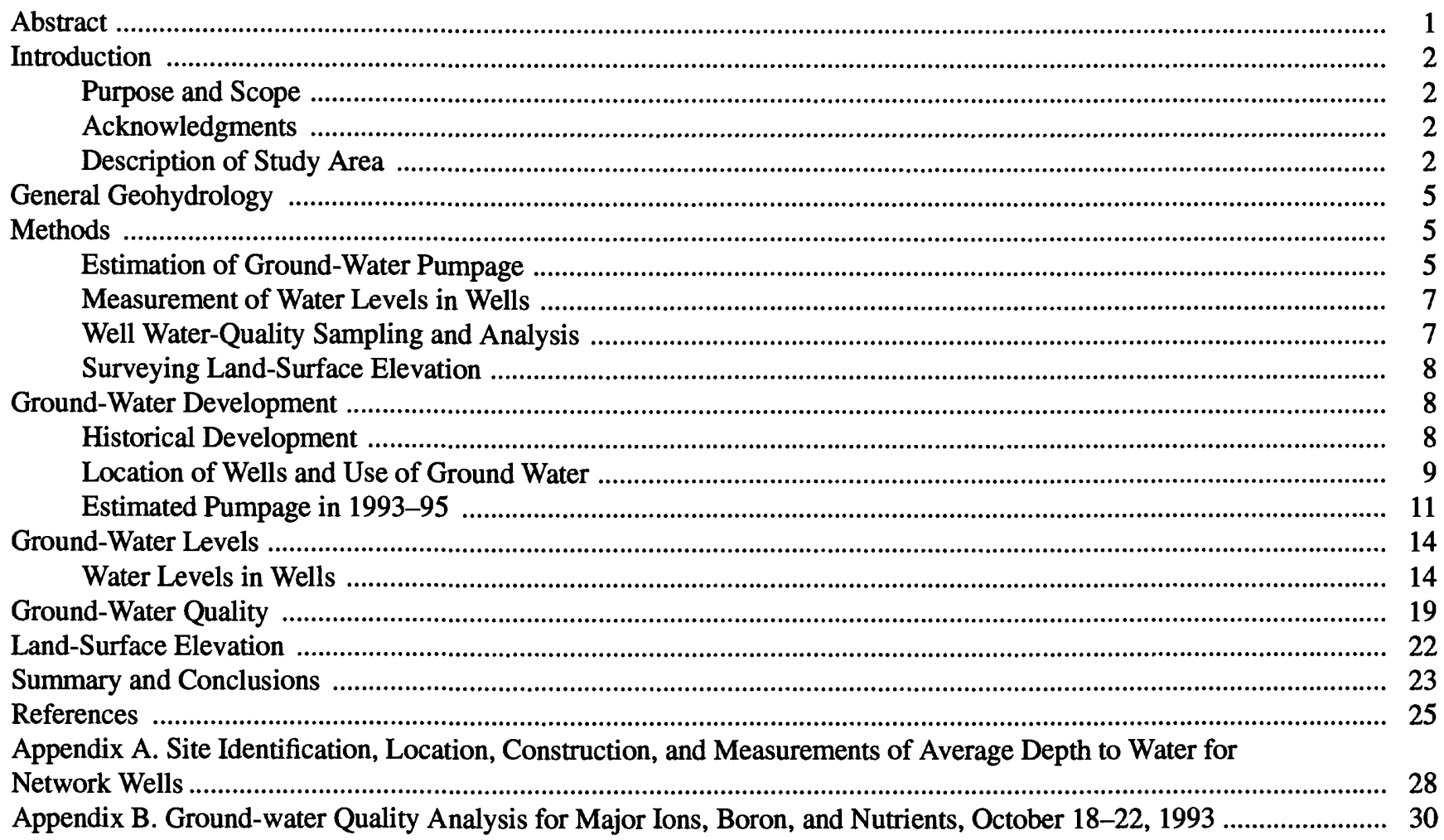

\section{FIGURES}

1.-5. Maps showing:

1. Location of the San Francisquito Creek alluvial cone surrounding Atherton, California .................................. 3

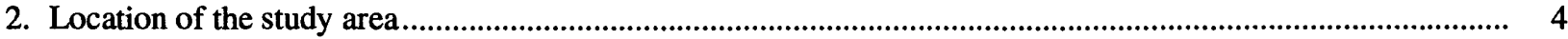

3. Land-surface elevation survey sites and well locations for water-level, water-quality, pumpage, and operation time data, April 1993 to December 1995

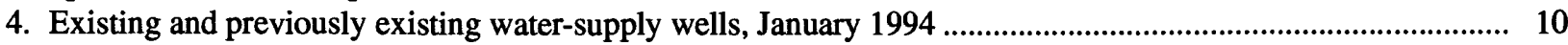

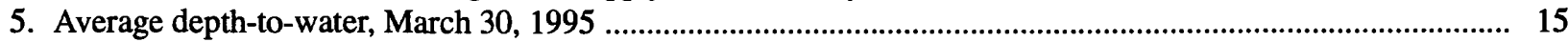

6. Graph showing depth to water levels in selected wells, April 1993 through December 1995................................ 16

7. Map showing change in water levels between October 6, 1994, and March 30, 1995 ....................................... 17

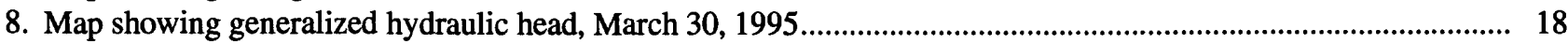

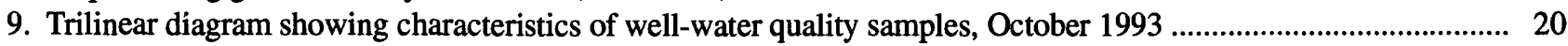

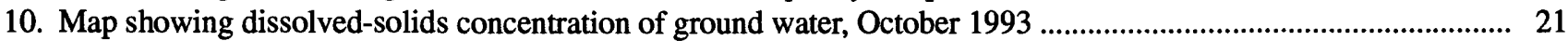

\section{TABLES}

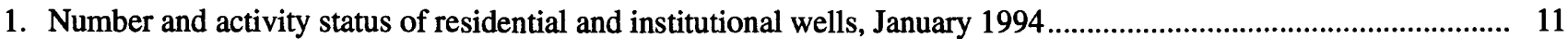

2. Ground-water pumpage data for network wells, April 1993 through September 1995.......................................... 12

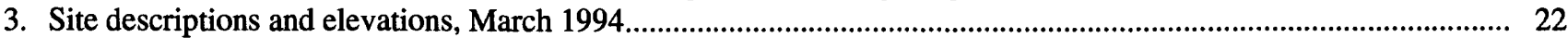


CONVERSION FACTORS, VERTICAL DATUM, ABBREVIATIONS, AND ACRONYMS

\begin{tabular}{rcl} 
Multiply & \multicolumn{1}{c}{ By } & To obtain \\
acre & 0.4047 & square hectometer \\
acre-foot (acre-ft) & 1,233 & cubic meter \\
acre-foot per day (acre-ft/d) & 1,233 & cubic meter per day \\
acre-foot per year (acre-ft/yr) & 1,233 & cubic meter per year \\
foot (ft) & .3048 & meter \\
foot per day (ft/d) & .3048 & meter per day \\
foot per year (ft/yr) & .3048 & meter per year \\
gallon (gal) & .00000307 & acre foot \\
gallon (gal) & .1337 & cubic foot \\
gallon per day (gal/d) & .003785 & cubic meter per day \\
gallon per minute (gal/min) & .003785 & cubic meter per minute \\
inch (in.) & 25.4 & millimeter \\
mile (mi) & 1.609 & kilometer \\
square mile (mi $\left.{ }^{2}\right)$ & 2.590 & square kilometer \\
\hline
\end{tabular}

Temperature is given in degrees Celsius $\left({ }^{\circ} \mathrm{C}\right)$, which can be converted to degrees Fahrenheit $\left({ }^{\circ} \mathrm{F}\right)$ by the following equation:

$$
{ }^{\circ} \mathrm{F}=1.8\left({ }^{\circ} \mathrm{C}\right)+32 .
$$

\title{
Vertical Datum
}

Sea level: In this report, "sea level" refers to the National Geodetic Vertical Datum of 1929 (NGVD of 1929)-a geodetic datum derived from a general adjustment of the first-order level nets of both the United States and Canada, formerly called Sea Level Datum of 1929.

\author{
Abbrevations \\ $\mathrm{h} / \mathrm{d} \quad$ hour per day \\ hp horsepower \\ ppm parts per million \\ $\mathrm{mg} / \mathrm{L} \quad$ milligram per liter \\ $\mu \mathrm{S} / \mathrm{cm} \quad$ microsiemen per centimeter at 25 degrees Celsius \\ $\mu \mathrm{g} / \mathrm{L} \quad$ microgram per liter
}

\section{Acronyms}

CADWR California Department of Water Resources

USGS U.S. Geological Survey 


\section{Well-Numbering System}

Wells are identified and numbered according to their location in the rectangular system for the subdivision of public lands. Identification consists of the township number, north or south; the range number, east or west; and the section number. Each section is divided into sixteen 40-acre tracts lettered consecutively (except I and $\mathrm{O}$ ), beginning with " $\mathrm{A}$ " in the northeast corner of the section and progressing in a sinusoidal manner to " $\mathrm{R}$ " in the southeast corner. Within the 40-acre tract, wells are sequentially numbered in the order they are inventoried. The final letter refers to the base line and meridian. In California, there are three base lines and meridians; Humboldt (H), Mount Diablo (M), and San Bernardino (S). All wells in the study area are referenced to the Mount Diablo base line and meridian (M). Well numbers consist of 15 characters and follow the format $005 \mathrm{~S} 003 \mathrm{~W} 33 \mathrm{~K} 003 \mathrm{M}$. In this report, well numbers are abbreviated and written $5 \mathrm{~S} / 3 \mathrm{~W}-33 \mathrm{~K} 3$. Wells in the same township and range are referred to only by their section designation, 33K3. The following diagram shows how the number for well $5 \mathrm{~S} / 3 \mathrm{~W}-33 \mathrm{~K} 3$ is derived.

RANGE

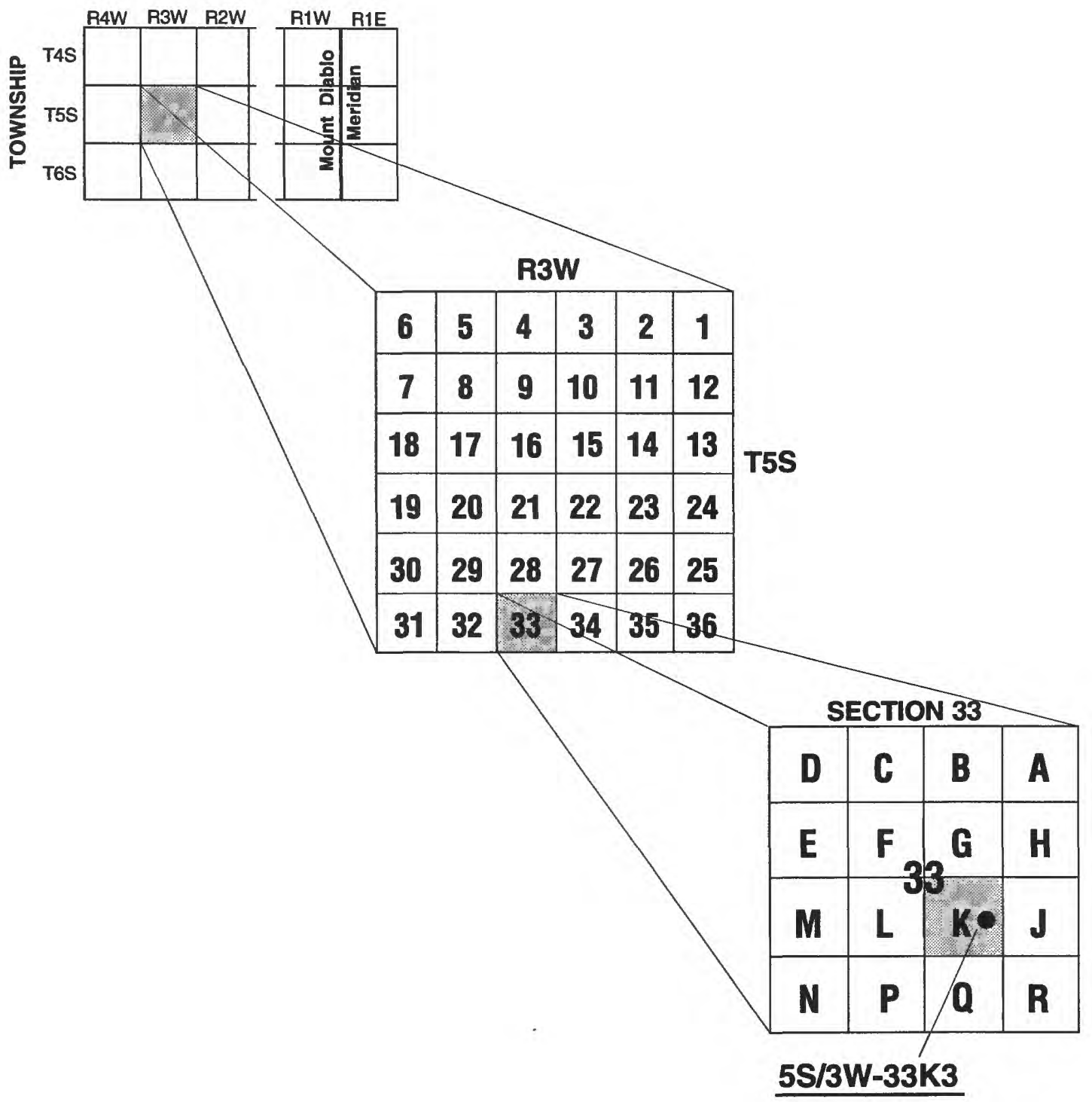




\title{
Ground-Water Development and the Effects on Ground-Water Levels and Water Quality in the Town of Atherton, San Mateo County, California
}

\author{
By Loren F. Metzger and John L. Fio
}

\section{Abstract}

The installation of at least 100 residential wells in the town of Atherton, California, during the 1987-92 drought has raised concerns about the increased potential for land subsidence and saltwater intrusion. Data were collected and monitoring networks were established to assess current processes and to monitor future conditions affecting these processes. Data include recorded pumpage, recorded operation time, and measured pumpage rates from 38 wells; water levels from 49 wells; water chemistry samples from 20 wells, and land-surface elevation data from 22 survey sites, including one National Geodetic Survey established bench mark. Geologic, lithologic, climatologic, well construction, well location, and historical information obtained from available reports and local, state, and Federal agencies were used in this assessment.

Estimates of annual residential pumpage from 269 assumed active residential wells in the study area indicate that the average annual total pumping rate is between 395 and 570 acre-feet per year. The nine assumed active institutional wells are estimated to pump a total of about 200 acrefeet per year, or 35 to 50 percent of the total residential pumpage. Assuming that 510 acre-feet per year is the best estimate of annual residential pumpage, total pumpage of 710 acre-feet per year would represent about 19 percent of the study area's total water supply, as estimated.

Depth-to-water-level measurements in wells during April 1993 through September 1995 typically ranged from less than 20 feet below land surface nearest to San Francisco Bay to more than 70 feet below land surface in upslope areas near exposed bedrock, depending on the season. This range, which is relatively high historically, is attributed to above normal rainfall between 1993 and 1995. Water levels expressed as hydraulic heads indicate the presence of three different hydrologic subareas on the basis of hydraulic-head contour configurations and flow direction. That all measured hydraulic heads in the study area from April 1993 through September 1995 were above sea level indicates that saltwater intrusion was unlikely during this period.

The chemistry of 20 well-water samples is characterized as a calcium magnesium carbonate bicarbonate type water. There is no evidence of saltwater intrusion from San Francisco Bay; however, water samples from wells nearest the bay and bedrock assemblages indicate a greater concentration of dissolved constituents and salinity.

Dissolved-solids concentrations of water samples from wells in these areas exceeded 1,000 milligrams per liter, and several samples contained a substantial fraction of sodium and chloride. Water hardness for the 20 wells sampled averaged 471 milligrams per liter as calcium carbonate, which is classified as very hard. One well sample exceeded the primary maximum contaminant level for drinking water in nitrate, several wells exceeded the secondary maximum contaminant level for chloride and sulfate, and all wells sampled exceeded the secondary maximum contaminant level for total dissolved solids. 
Land-subsidence and the resultant damage because of excessive ground-water pumping, in combination with periodic drought, have a welldocumented history in the south San Francisco Bay area. Land-elevation surveying data from 1934 to 1967 indicate that subsidence ranged from 0.1 to approximately 0.5 foot in the vicinity of the study area. It could not be determined from landsurface elevation surveying data from 1993 whether subsidence is currently occurring in the study area.

\section{INTRODUCTION}

Water resources in the south San Francisco Bay and peninsula area of California are used for municipal, industrial, domestic, and agricultural purposes. The principal sources of water are local surface-water runoff, imported surface water conveyed from the Sierra Nevada through the Hetch Hetchy Aqueduct, and ground water from local aquifers. As the cost of imported surface water has increased, ground water has become an important source of supplemental water for domestic irrigation. The effect of this ground-water pumping on the local and regional ground-water resources, however, is not well understood. Problems associated with historical pumping practices are evident in parts of the south San Francisco Bay area in the form of land subsidence and saltwater intrusion, which are related to declining ground-water levels. Examples of the consequences of aquifer dewatering include the following: land subsidence of up to $13 \mathrm{ft}$ in the San Jose area between 1916-67, which is $20 \mathrm{mi}$ southeast of the study area (Poland and Ireland, 1988); and saltwater intrusion in the Palo Alto Baylands area, which is $5 \mathrm{mi}$ east of the study area. The U.S. Geological Survey, in cooperation with the town of Atherton, California, conducted a study from April 1993 through September 1995 to help determine the effects of domestic irrigation on ground-water resources.

\section{Purpose and Scope}

This report presents the results of a study done within the San Francisquito cone (fig. 1), an alluvial fan that extends eastward from the Santa Cruz Mountains into San Francisco Bay in southern San Mateo County, California. During the study, the effects of pumping on ground-water levels and quality were assessed and a framework was established for future monitoring of geohydrologic conditions and land subsidence in the area. This assessment was done using estimates of annual pumpage, measured water levels in wells, chemical analyses from well-water samples, the establishment of a network of sites for monitoring land subsidence, and lithologic and geologic data from welldriller logs and previously published reports and maps.

\section{Acknowledgments}

The authors wish to express their gratitude to those who helped make this report possible. Numerous property owners allowed repeated access to their wells for water-level and discharge measurements and waterquality sampling. Special thanks to the volunteers of the Atherton Civic Interest League and to Don McPherson and Kathy Hughes, town of Atherton, for their assistance in compiling data. Likewise, U.S. Geological Survey employees Lee Price and Marti Ikehara were invaluable for carrying out the water-quality and elevation surveying components of the study.

\section{Description of Study Area}

The town of Atherton is a 6-mi² residential area in southern San Mateo County between the cities of Menlo Park and Palo Alto to the south and east and Woodside and Redwood City to the west and north (fig. 1). Northern Atherton gently slopes toward the south from about 25 to $120 \mathrm{ft}$ above sea level where the study area contacts consolidated rock. The hilly terrain of the southern quarter of Atherton attains elevations above $300 \mathrm{ft}$. Originating beyond the southern boundary of Atherton, Atherton Channel serves as the study area's primary conduit for runoff. San Francisquito Creek, an intermittent creek, is south of the study area and drains storm runoff from approximately $40 \mathrm{mi}^{2}$ of upslope mountainous terrain and a narrow corridor of about 7 $\mathrm{mi}^{2}$ of developed land adjacent to the creek (California Department of Water Resources, 1967; U.S. Army Corps of Engineers, 1972). The area's climate is characterized as warm and dry in summer and moist and wet in winter. Annual rainfall ranges from about 16 in. in northern Atherton to more than 20 in. in the hills of southern Atherton (Rantz, 1971).

For this report, the study area was divided into four subareas; the northern (N), western (W), eastern (E), and bedrock (S) subareas (fig. 2). The N, W, and E 


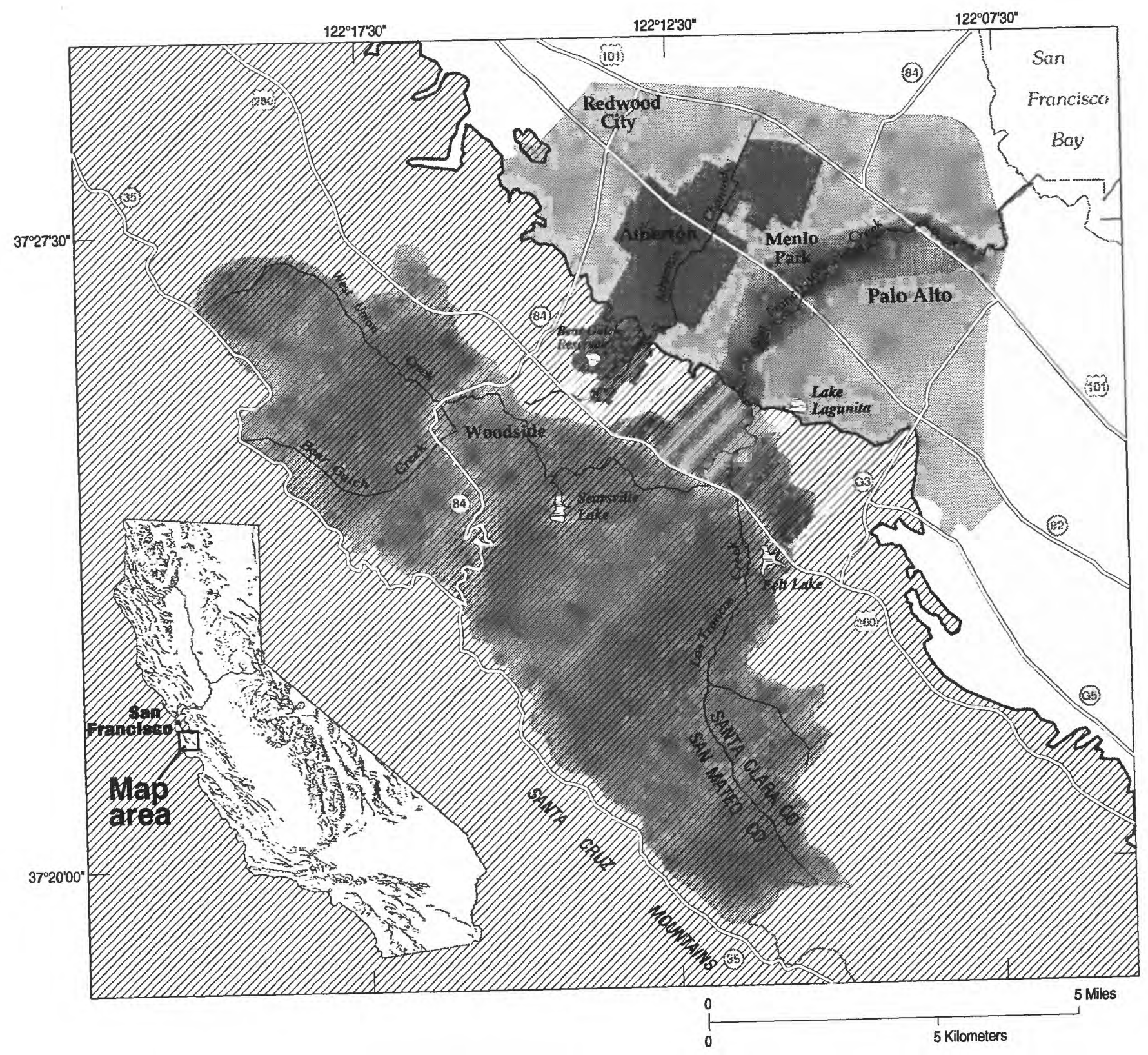

\section{EXPLANATION}

Alluvium outside of San Francisquito Creek alluvial cone

San Francisquito Creek alluvial cone

San Francisquito Creek drainage basin

Study area

गIIIII, Consolidated rock

Figure 1. Location of the San Francisquito Creek alluvial cone surrounding Atherton, California. 


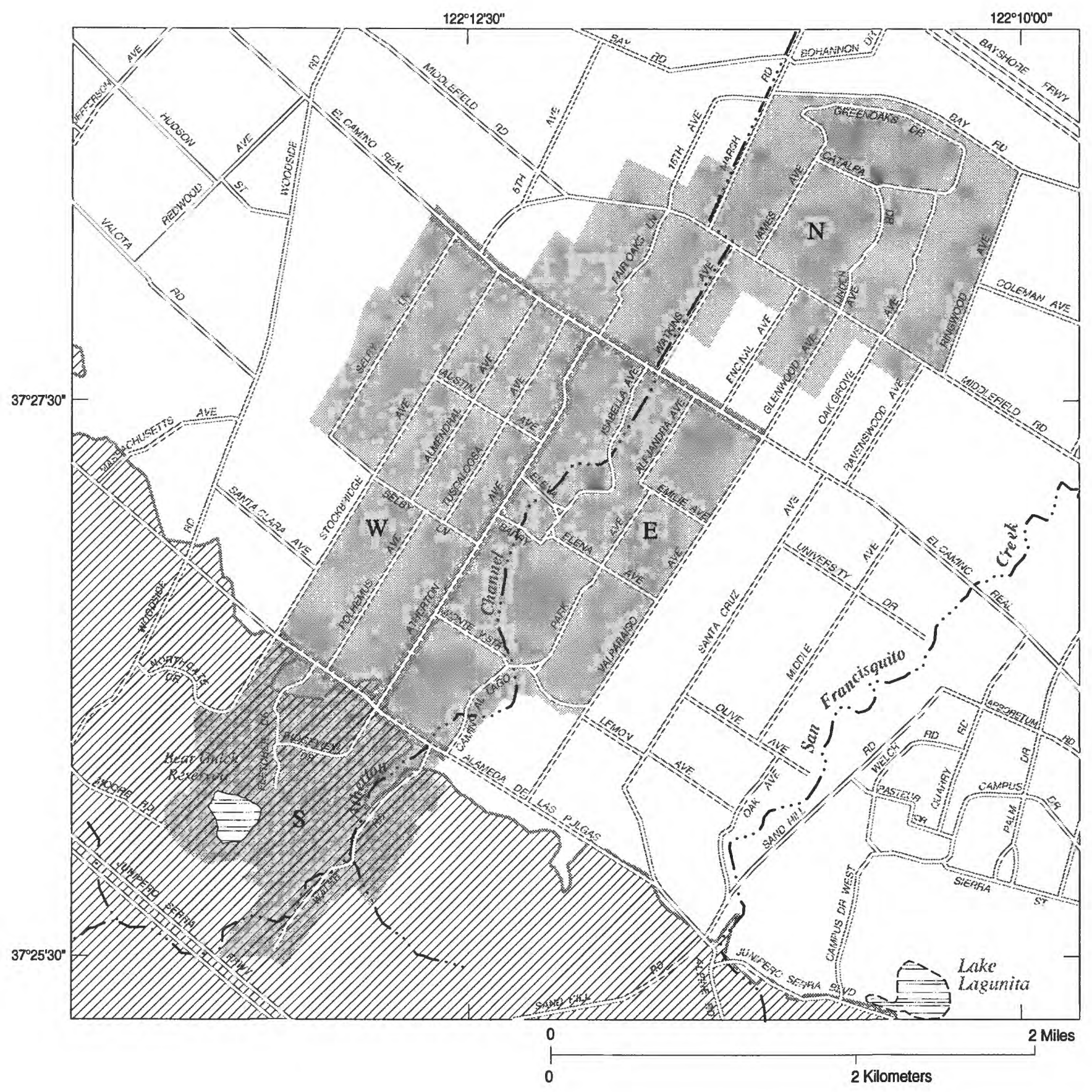

EXPLANATION

Study area

TITIY Consolidated rock

Subarea boundary

Figure 2. Location of the study area, Atherton, California. 
subareas are delineated by general, nonspecific boundaries, whereas the boundary between the $S$ subarea and three downslope subareas is formed by the contact between exposed consolidated rock and unconsolidated alluvial deposits. The $\mathrm{N}$ subarea is nearest San Francisco Bay, extending south to approximately El Camino Real (Highway 82). The W and $\mathrm{E}$ subareas are south of El Camino Real and separated by Atherton Avenue. The E subarea is the part of the study area nearest San Francisquito Creek.

\section{GENERAL GEOHYDROLOGY}

Incongruent with the surface drainage basin associated with San Francisquito Creek is an alluvial fan referred to as the San Francisquito alluvial cone (fig. 1). A northwestern extension of the Santa Clara Valley ground-water basin, the San Francisquito cone encompasses an area of about $22 \mathrm{mi}^{2}$ and is bounded by exposed consolidated rock of the foothills of the Santa Cruz Mountains to the southwest and by San Francisco Bay to the northeast; no natural features clearly define the northwest or southeast boundaries (Sokol, 1964).

The San Francisquito cone is a semiconfined aquifer underlain by consolidated rock, which is as deep as $500 \mathrm{ft}$ below land surface within the study area. Subsurface geology is characterized by a predominance of discontinuous lenses of unconsolidated coarse- and fine-grained sediments of Pleistocene and Holocene age (Fio and Leighton, 1995). Typical of alluvial fan structure, the texture of the San Francisquito cone's alluvium is largely a function of its relative position on the fan (Belitz and Heimes, 1990). Lithologic logs and geologic literature for the area indicate that coarse-grained deposits (sand and gravel) become more abundant in upslope areas closer to the consolidated rock/alluvium contact and adjacent to both present day and ancient stream channels (Pampeyan, 1993). Conversely, toward lower elevations of the cone nearest San Francisco Bay, alluvial sediments become progressively fine-grained, such as clay, silt, and sandy clay, with a relatively small amount of coarse-grained sediment.

Areas having a greater abundance of finegrained sediments, including the $\mathrm{N}$ subarea and adjacent parts of the E subarea, are more susceptible to land subsidence because of the greater compressibility of these sediments (Pewe, 1990). Lowering of the water table through pumpage and(or) drought reduces the water pressure in pore spaces between grains of sedi- ment. This drop in water pressure reduces the water's buoyancy on the overlying sediments and consequently increases intergranular stress. The resulting compaction of these deposits and associated reduction in pore space between grains can result in sinking or settlement of land surface and also can reduce the ground-water storage capacity. This compaction may be reversible, depending on the severity of the compressional stress.

Recharge, in conjunction with discharge, governs the overall condition of the aquifer system. Sokol (1964) estimated that annual recharge to the San Francisquito cone was about 3,000 acre-ft. Ground-water recharge probably is greatest through infiltration into the coarse-grained deposits associated with San Francisquito Creek and the unlined parts of Atherton Channel; however, the amount and distribution of recharge in the study area are not well understood. Other potential sources of recharge include area lakes and reservoirs, infiltration of precipitation and(or) irrigation water, and leakage from water mains and sewer pipes. For example, San Francisco's water and sewage pipe leakage has been estimated to account for about half of that area's total recharge (Phillips and others, 1993). Ground-water inflow from adjacent basins also may exist (California Department of Water Resources, 1967). Discharge typically occurs from ground-water pumping in downslope areas, evapotranspiration, and seepage of ground water to surface-water features. Ground-water outflow to adjacent ground-water basins (Sokol, 1964) and to San Francisco Bay also may exist.

\section{METHODS}

Data collected from March 1993 through September 1995 include recorded pumpage, recorded operation time, and measured pumpage rates from 38 wells; water-levels from 49 wells; water-quality samples from 20 wells; and land-surface elevation data from 22 sites, including one National Geodetic Survey established bench mark (fig. 3). These data were compiled into a regional ground-water database for the greater south San Francisco Bay area (Leighton and others, 1995). This database was used to conduct spatial analyses of the data.

\section{Estimation of Ground-Water Pumpage}

Twelve wells in the monitoring network were equipped with inline flowmeters for recording well 

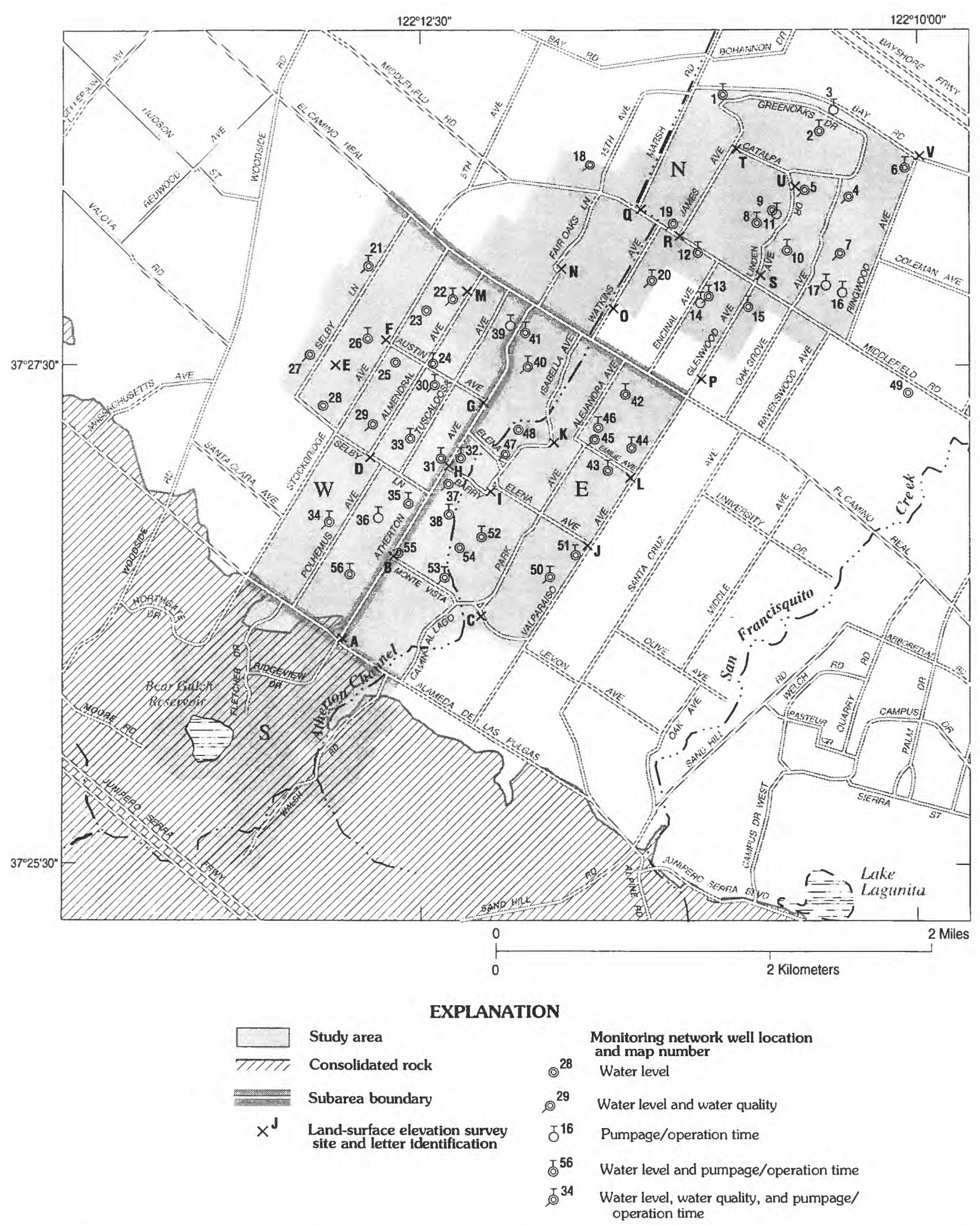

Figure 3. Land-surface elevation survey sites and well locations for water-level, water-quality, pumpage, and operation time data in Atherton, California, April 1993 to December 1995. 
pumpage. The flowmeters recorded cumulative pumpage from the date of meter installation. Meter readings were routinely collected biweekly to quarterly, at a minimum. Neither accuracy nor precision of these meters were tested specifically as part of this study. Assessing the quality of inline flowmeter readings requires either laboratory testing or on-site comparison with velocity meters under normal well-operating conditions.

Uncertainty regarding the quality of the inline flowmeter readings, and the limited number of accessible wells for which such information could be obtained, necessitated the use of a portable Doppler ultrasonic flowmeter at 29 wells. A Doppler ultrasonic flowmeter consists of two clamp-on transducers mounted on opposite sides of the well discharge pipe and connected to a battery-powered microprocessor. Operation requires the presence of air bubbles or suspended particles in the flowing medium. Either of these heterogeneities causes a shift in frequency between transmitted and received signals, which in turn are converted by the microprocessor into a velocity or flow rate (Smith and Mylvaganam, 1993). Ideal conditions for relatively clean fluids, such as water, require that the transducers be placed several pipe diameters downstream of a $90^{\circ}$ elbow where turbulence in the discharge pipe is greatest.

Cumulative well operation was measured at 21 wells beginning in April 1994 using time totalizers. Time totalizers were strapped to the outside of the well discharge pipe to record cumulative well operation by sensing the vibrations of the well pump and the discharge of water. Then, ground-water pumpage was estimated for each monitoring network well having at least inline flowmeter or Doppler ultrasonic flowmeter data.

\section{Measurement of Water Levels in Wells}

Water levels were measured on a biweekly to quarterly basis in 49 wells between April 1993 and September 1995. The period of record for most wells is 1 year or more, but some were measured for less than 1 year.

Maps of mean depth-to-water and hydraulic head were made using data from April 1993 through September 1995. Hydraulic-head values were calculated by subtracting the measured depth-to-water from the land-surface elevation at the well. Land-surface elevation was determined by interpolating between $5-\mathrm{ft}$ contour intervals from USGS 7-1/2-minute topographical map for the Palo Alto Quadrangle (accuracy \pm 2.5 $\mathrm{ft}$ ).

An electric sounder was used to measure water levels in 46 wells and a steel tape was used for the remaining 3 wells. To obtain water-level measurements representative of unpumped conditions, site visits were planned to maximize the time between well use and water-level measurements. When possible, well owners were asked to refrain from using their well on the night before a site visit. Site visits also were scheduled to avoid known irrigation periods, such as early morning or evening. Sites were noted where the well had been recently pumped, which was indicated by water-level recovery or wet vegetation. More than 90 percent of the total number of water-level measurements made between April 1993 and September 1995 represented unpumped conditions. However, at individual sites, recently pumped conditions were observed on as many as half of the visits. Measurements made under recently pumped conditions were not used for mapping purposes.

\section{Well Water-Quality Sampling and Analysis}

Twenty wells were sampled in October 1993 for major ions, boron, nutrients, alkalinity, specific conductance, $\mathrm{pH}$, and temperature. In accordance with USGS sampling protocol (Wood, 1976), sampled wells were purged of a minimum of three casing volumes. Successive measurements of specific conductance, $\mathrm{pH}$, and temperature were made at 5-minute intervals until the readings for these constituents for three consecutive samples stabilized, indicating that constant conditions had been reached. Before sampling, all sample collection, filter apparatus, and storage containers were thoroughly rinsed with well water, and portable $\mathrm{pH}$ meters and electrodes were calibrated with $\mathrm{pH}$ buffers that were maintained at the temperature of the sample water.

Ground-water samples were collected in a churn splitter from a hose bib near or at the well and subsequently separated into subsamples for on-site and laboratory analyses. On-site analyses were done immediately after sample collection for determination of alkalinity and bicarbonate concentrations because these constituents are subject to change upon exposure to ambient atmospheric conditions. Four subsamples were processed for analysis in accordance with USGS national water-quality preservation requirements: a 
subsample for calcium (Ca), magnesium (Mg), sodium $(\mathrm{Na})$, and potassium $(\mathrm{K})$ was filtered and preserved with nitric acid; a filtered subsample for sulfate $\left(\mathrm{SO}_{4}\right)$, chloride $(\mathrm{Cl})$, fluoride $(\mathrm{F})$, silica $\left(\mathrm{SiO}_{2}\right)$, and boron $(\mathrm{B})$ was bottled without preservation; an unfiltered and untreated subsample was allocated for specific conductance (EC), pH, lab alkalinity, and total dissolved solids (TDS); and a filtered subsample was preserved with mercuric chloride and chilled for nutrient analysis of nitrate-nitrogen $\left(\mathrm{NO}_{2}+\mathrm{NO}_{3}\right.$, dissolved as $\left.\mathrm{N}\right)$.

Major ions, silica, and boron were analyzed at the USGS National Water-Quality Laboratory in Arvada, Colorado. Calcium, magnesium, sodium, potassium, and silica were determined by atomic absorption spectrometry. Chloride and fluoride were determined by colorimetry. Boron was determined by atomic emission spectrometry. Sulfate was determined by the turbidimetric procedure. These methods are described by Fishman and Friedman (1989).

\section{Surveying Land-Surface Elevation}

Twenty-two sites distributed in a grid-like fashion throughout the study area were chosen for landsurface elevation surveying. Most land-surface elevation surveying sites (sites) are identified by a nail and a painted washer set in concrete. Some of the sites include other objects such as fire hydrants and concrete fence posts. Land-surface elevations were derived from third-order differential leveling to an accuracy of $0.001 \mathrm{ft}$. Elevations for these sites were adjusted along level lines originating at National Geodetic Survey bench mark R888 on consolidated rock in the southern part of the study area (fig. 3, land-elevation surveying site A).

\section{GROUND-WATER DEVELOPMENT}

\section{Historical Development}

Initial water needs in the study area were met with diversions from Bear Gulch Creek by the area's earliest purveyors: the Arroyo de la Presa Water Company, 1863; Corte Madera Water Company, 1863; Menlo Park Water Company, 1873; and Bear Gulch
Water Company, 1889 (Poulter, 1934). Private wells were pumped for ground water in the early 1900's to irrigate multi-acre estates because of the lack of dependable, year-round surface-water supplies. By the mid-1910's, at least a dozen privately owned wells were used for irrigating crops and general landscaping (Clark, 1924). Water-level measurements made at 18 wells during the summer of 1915 indicated that water levels ranged from 5 to $15 \mathrm{ft}$ above sea level in the $\mathrm{N}$ subarea and from 10 to $60 \mathrm{ft}$ above sea level in the $E$ and W subareas (Clark, 1924), which translates to about 20 and $80 \mathrm{ft}$ below land surface in the $\mathrm{N}$ and $\mathrm{E}$ subareas in the context of depth-to-water.

Because of below normal rainfall and the need for new water service connections, the Bear Gulch Water Company constructed two wells in 1924 with a combined capacity of nearly $400 \mathrm{acre}-\mathrm{ft} / \mathrm{yr}$. These wells were drilled near the northeastern corner of the study area; one northeast of the intersection of Fifth Avenue and Middlefield Road and the other between the eastern extension of Bay Road and Highway 101 (Poulter, 1934; Michael Rossi, California Water Services Company, written commun., 1994). Water supplies were further augmented that year with a connection to a San Francisco Water Department transmission line, which allowed the conveyance of Hetch Hetchy Aqueduct water to the Bear Gulch Reservoir. By the mid-1920's, the total number of private wells in and adjacent to the study area increased to more than 100 and contributed to the 6,000 acre-ft of total annual pumpage from the San Francisquito cone (Lee 192325; Lee, 1925). Pumping and below normal rainfall in the early and mid-1920's resulted in substantial drawdown of water levels to the point that some wells near the foothills were dry for several years (Lee, 1925). In many areas, water levels declined more than $60 \mathrm{ft}$ at a rate of about $10 \mathrm{ft} / \mathrm{yr}$ between 1923 and 1926 (Lee, 1924-26). In contrast, before 1919 , water levels "...in pumped wells stood at a more-or-less stationary level above the surface of San Francisco Bay..." throughout the year (Lee, 1924-26). In the spring of 1925, water levels in numerous wells in the $\mathrm{E}$ and $\mathrm{W}$ subareas ranged from 25 to $40 \mathrm{ft}$ below sea level ( 85 to $115 \mathrm{ft}$ below land surface), with pumping levels more than 90 $\mathrm{ft}$ below sea level in several wells at the end of the 1926 pumping season (Lee, 1924-26). 
A ground-water survey in 1931 (Don Schuder, California Department of Water Resources, written commun., 1993) indicates that pumping continued into the 1930 's, with some wells capable of producing more than 40 acre-ft/yr. This ground water was used primarily to irrigate orchards, alfalfa, flowers, and lawns and to fill swimming pools. During the 1930's and 1940's, annual pumpage was at least 200 to $300 \mathrm{acre}-\mathrm{ft} / \mathrm{yr}$, not including production from four additional wells southeast of the study area that were leased by the Bear Gulch Water Company and its successor, the California Water Service Company, until the mid-1930's (Michael Rossi, California Water Service Company, written commun., 1994). Concurrently, the benefits of the doubled capacity of Bear Gulch Reservoir had been fully realized, and the Hetch Hetchy connection, which up until that time had been regarded as an emergency water supply, was pressed into service (Michael Rossi, California Water Service Company, written commun., 1994). By 1950, the California Water Service Company was forced to discontinue pumping and shortly thereafter to abandon its two wells just outside the northeastern boundary of the study area because of a deterioration in water quality that began in 1936; chloride levels were measured in excess of $500 \mathrm{ppm}$ and water hardness at about $850 \mathrm{ppm}$ in the spring of 1950 (Michael Rossi, California Water Service Company, written commun., 1994).

Drillers logs for 14 wells that were scattered throughout the $\mathrm{N}$ subarea and northern parts of the $\mathrm{W}$ and $\mathrm{E}$ subareas indicate that water levels in wells during the early and mid-1950's generally were from $15 \mathrm{ft}$ below to $15 \mathrm{ft}$ above sea level, irrespective of landsurface elevation (25-70 ft). Severe drought conditions during 1959-61 resulted in overdraft conditions that exceeded those during the 1920's; water levels in wells ranged from 91 to $98 \mathrm{ft}$ below sea level (141-148 $\mathrm{ft}$ below land surface) in two wells in the $\mathrm{N}$ subarea between El Camino Real and Middlefield Road and from 86 to $90 \mathrm{ft}$ below sea level (169-173 ft below land surface) in one well just outside the E subarea near Valparaiso Avenue (Sokol, 1964). Before 1962, annual pumpage for the San Francisquito cone was about 7,500 acre-ft, all but 1,000 acre-ft of which was accountable to the city of Palo Alto and Stanford University (Sokol, 1964). Sokol does not indicate how the 1,000 acre-ft was distributed among existing residential and institutional wells. The city of Palo Alto and
Stanford University ceased regular pumping in 1962 because of possible aquifer dewatering and associated land subsidence. Water-use records from the mid1970 's through 1994 indicate that these two entities typically pumped several hundred acre-ft of ground water annually (S. Scott Seeley, Hilton, Farnkopf, and Hobson, written commun., 1993).

Recent drought conditions during 1976-77 and 1987-92 resulted in increased well installations in the study area. Almost 100 new residential wells were installed during the 1987-92 drought. These installations coincided with mandatory water rationing of potable surface-water supplies and financial penalties for exceeding the baseline water use of $748 \mathrm{gal} / \mathrm{d}$ per residential connection (Clay Scofield, California Water Service Company, Bear Gulch District, oral commun., 1994).

\section{Location of Wells and Use of Ground Water}

As of January 1994, more than 500 water-supply wells exist or have existed in the study area (fig. 4). Maps and lists of well locations reported by Clark (1924) and Lee (1925) indicate that about 100 additional wells are not accounted for in figure 4 . About 95 percent of the wells identified are used for private domestic irrigation, although some older wells may have been used to supply potable water to individual households (Don Schuder, California Department of Water Resources, written commun., 1993). Most residential properties with wells are about 1-1/4 acres, but some are almost 10 acres. Landscaping generally accounts for 50 to 75 percent of the total area of these properties. About 5 percent of the wells are used by institutions to irrigate landscaping and athletic fields, and they sometimes provide potable water for seasonal student populations. Institutional wells supply water to areas that range from 10 to 60 acres.

At least two-thirds of the total annual pumpage in the study area occurs during the irrigation season (May through October). Pumpage is affected by parcel size and the part of it irrigated by the well, the type of vegetation irrigated, the irrigation system (automatic or manual), the relative percentage of ground water and surface water used (many landowners use both), and other factors. Well use during the irrigation season can 


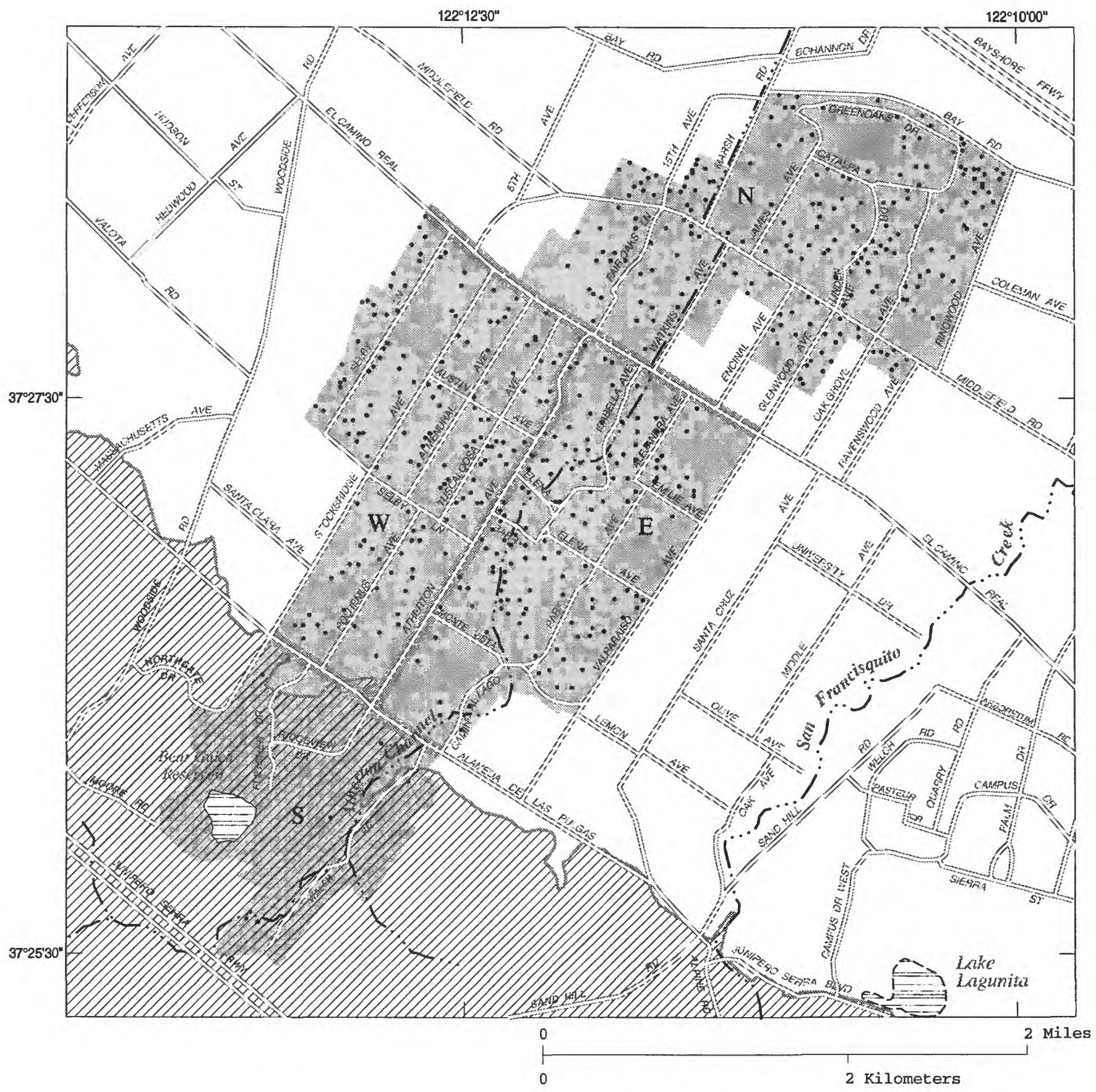

\section{EXPLANATION}

\section{Study area}

mylymy, Consolidated rock

Subarea boundary

- Well location

Figure 4. Existing and previously existing water-supply wells in Atherton, California, January 1994. 
range from several hours per week to almost $24 \mathrm{~h} / \mathrm{d}$ several days per week.

\section{Estimated Pumpage in 1993-95}

A combination of mail surveys, site visits, well drillers' logs, and other reports and paper records indicate that at least 175 of the 503 wells identified within the study area were being used in 1993-95 (table 1). Available information indicates that an additional 103 wells also could be considered active, resulting in a total of at least 278 residential and institutional wells assumed active in 1993-95. Eighty-one remaining wells were confirmed inactive, 19 wells could not be located, and the status of 125 wells could not be determined. Therefore, the total number of potentially active residential and institutional wells ranged from a minimum of 175 confirmed active to a maximum of 403 (the sum of total confirmed active, probably active, and unknown well totals) (table 1).

Average pumpage from residential wells during April 1993 through September 1995 was estimated from the number of assumed active ("confirmed active" plus "probably active," table 1) residential wells in the study area (269) and the average daily pumping rate calculated for 19 network wells (table 2). The average daily pumping rate was derived from inline flowmeter data, Doppler ultrasonic flowmeter and time-totalizer data, or the average of both data combinations where available (table 2). Eleven wells equipped only with inline flowmeters pumped at an estimated average rate of $0.00582 \mathrm{acre}-\mathrm{ft} / \mathrm{d}$, which contrasts with an estimated average rate of 0.00402 acre- $\mathrm{ft} / \mathrm{d}$ for 12 wells equipped with time-totalizers and measured using a Doppler ultrasonic flowmeter. If applied to all assumed active wells in the study area (269), these estimated daily pumping rates would translate to annual residential pumpage totals of about 570 and 395 acre-ft, respectively. Because of the uncertainty of which measurement technique is more accurate, an estimate of total residential pumpage using wells that have either or both inline flowmeter and Doppler ultrasonic flowmeter estimates was used. This average daily pumping rate of 0.00521 acre- $\mathrm{ft} / \mathrm{d}$ (table 2) multiplied by the 269 assumed active residential wells equals an estimated total residential pumpage of about $510 \mathrm{acre}-\mathrm{ft} / \mathrm{yr}$.
Table 1. Number and activity status of residential and institutional wells in Atherton, California, January 1994

\begin{tabular}{lccc}
\hline $\begin{array}{c}\text { Well activity } \\
\text { classification }\end{array}$ & \multicolumn{2}{c}{ Number of wells identified } & Total \\
\cline { 2 - 3 } & Residential & Institutional & \\
\hline Confirmed active .......... & 166 & 9 & 175 \\
Probably active ............ & 103 & 0 & 103 \\
& & & \\
Inactive ...................... & 81 & 0 & 81 \\
$\begin{array}{l}\text { No well found.............. } \\
\text { (presumed }\end{array}$ & 18 & 1 & 19 \\
destroyed) & & & \\
& & & \\
Unknown .................... & 125 & 0 & 125 \\
Totals .......................... & 493 & 10 & 503 \\
\hline
\end{tabular}

Institutional well use is substantially greater on an individual well basis than is residential use. For example, a comparison of institutional and residential well operation time shows that daily use of 4 institutional wells averages $2.88 \mathrm{~h} / \mathrm{d}$ versus daily use by 17 residential wells that averages $0.98 \mathrm{~h} / \mathrm{d}$ (table 2 ). The nine assumed-active institutional wells in the study area generally are equipped with 20 - to 30 -hp pumps that can produce upwards of several hundred gallons per minute. Doppler measurements at six of the institutional wells showed average measured pumpage rates ranging from about 40 to $260 \mathrm{gal} / \mathrm{min}$ (table 2). Assuming an average daily pumpage rate of 0.06166 acre-ft/d, on the basis of time-totalizer data and Doppler ultrasonic flowmeter measurements from four institutional wells, average total pumpage by the nine assumed active institutional wells in the study area is estimated to be about 200 acre-ft/yr.

For comparison, average daily surface-water deliveries from the California Water Service Company's Bear Gulch system to the study area during July 1993 through June 1995 averaged 8.12 acre-ft/d (2,963 acre-ft/yr) (Jay Perrine, California Water Service Company, written commun., 1995). Total residential and institutional pumpage of about $710 \mathrm{acre}-\mathrm{ft} / \mathrm{yr}$, therefore, represents more than 19 percent of the total water supply, as estimated.

Considerable uncertainty in well pumpage rates of residential and institutional wells, operation time, and the number of active wells limits reliable estima- 


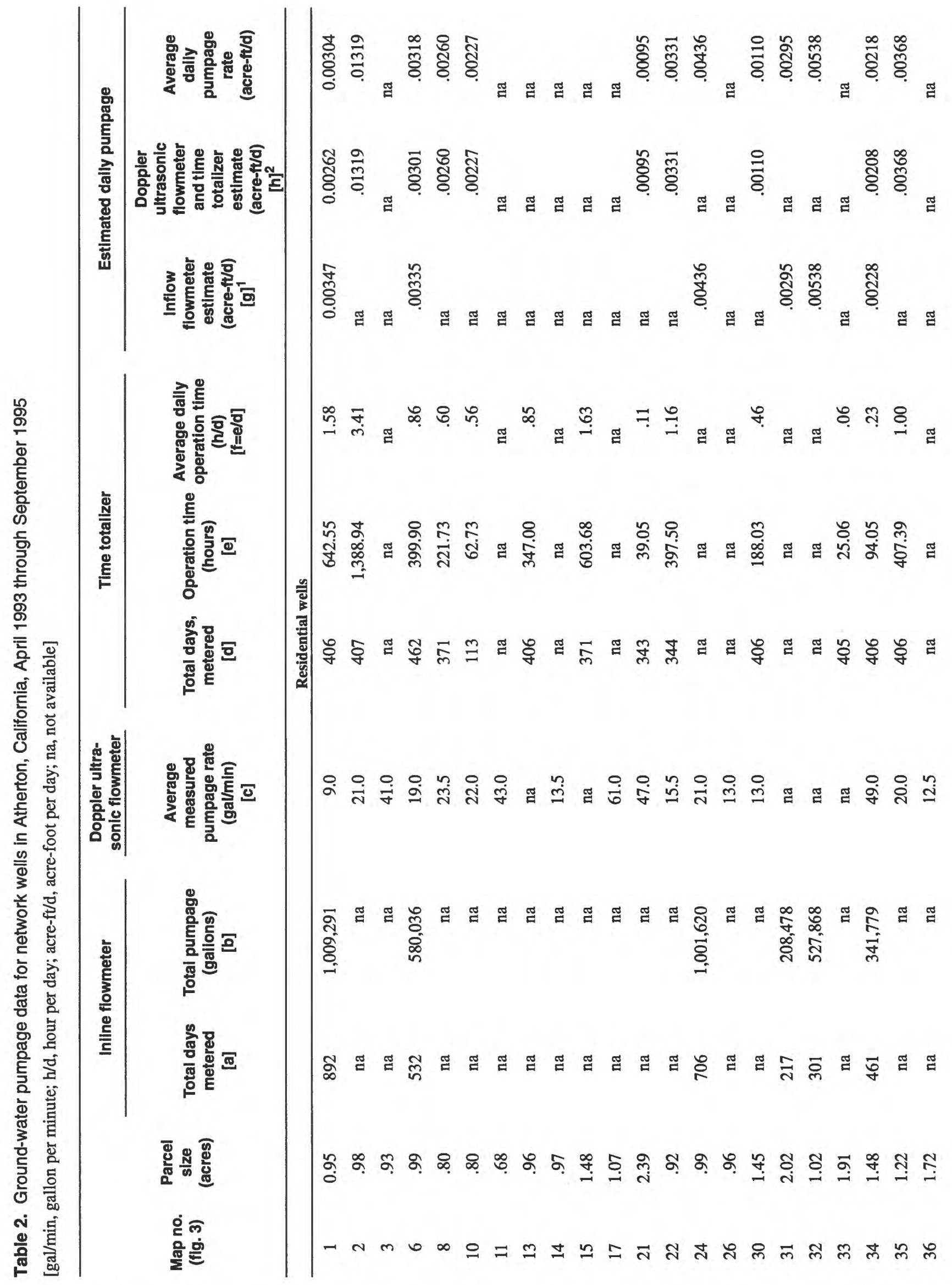




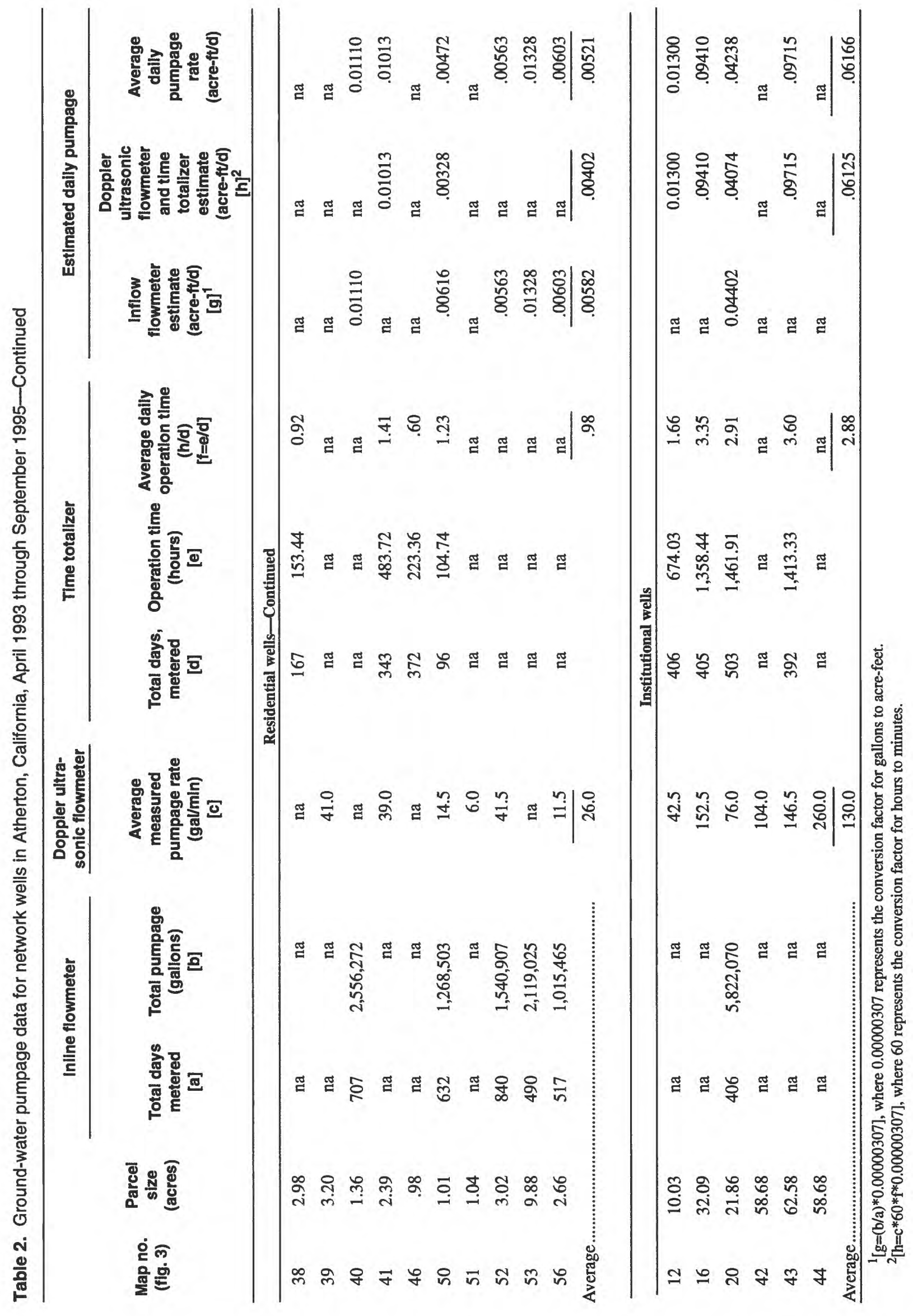


tion of total annual pumpage for the study area. For example, the number of active residential wells in the study area ranges from a minimum of 166 "confirmed active" to a maximum of 394 " confirmed active" + "probably active" + "unknown." If the average daily pumpage rate, average daily operation time, and the average measured pumpage rate are representative of residential wells for the study area, then average residential pumpage can range from a minimum of about $315 \mathrm{acre}-\mathrm{ft} / \mathrm{yr}$ to almost $750 \mathrm{acre}-\mathrm{ft} / \mathrm{yr}$. Another consideration is parcel size; if daily pumpage is a function of parcel size, then the 19 residential network properties with well data used to estimate total residential pumpage (average size 1.91 acres) are not representative of the typical property with a well (1.27 acres) in the study area. Adjusting for parcel size would yield an estimate of about 340 acre-ft/yr for 269 assumed active residential wells. The correlation between parcel size and well use is undefinitive, as shown in table 2.

Improvement of pumpage estimates can be accomplished by addressing the key unknowns. Institutional wells, as a whole, may account for $\mathbf{3 0}$ to 50 percent of total pumpage. There are only nine assumed active institutional wells, so metering these wells may provide a substantial improvement of pumpage estimates with minimal effort. Metering of all residential wells may be impractical, but installation of inline flowmeters on a subset of these wells, combined with an official determination of the number of active residential wells, could provide a more reliable means for estimating total residential pumpage.

\section{GROUND-WATER LEVELS}

\section{Water Levels in Wells}

Water-level monitoring can serve as an early indicator of potentially deleterious effects on an aquifer because of excessive pumping and(or) deficient recharge. In the example of the Santa Clara Valley's recent experience (Iwamura, 1980; Poland and Ireland, 1988), ground-water-level declines below sea level were a precursor to regional land subsidence and saltwater intrusion of areas immediately adjacent to San Francisco Bay. Water levels can be expressed in two ways: as depth-to-water below land surface or as hydraulic head. Hydraulic head is particularly useful because it expresses water level as an altitude relative to an arbitrary datum plane, which is usually sea level. Because ground water moves in the direction of decreasing head, contour maps of hydraulic head can be used to determine the general direction of groundwater flow in an aquifer.

Average depth-to-water level measurements for network wells during April 1993 through September 1995 are listed in appendix A. These measurements do not necessarily represent the water table because hydraulic head can vary with depth within an aquifer. Therefore, the water level in wells open to large intervals and not open at the water table may not represent the water table. An example of depth-to-water conditions during this period is shown in figure 5 for March 1995. Depth-to-water on March 30, 1995, ranged from about $16 \mathrm{ft}$ below land surface in the $\mathrm{N}$ subarea to more than $68 \mathrm{ft}$ below land surface in the E subarea. Measurements at that time generally were several feet above the 1993-95 averages (appendix A), reflecting preirrigation season conditions in conjunction with above normal rainfall from October 1994 through March 1995; as of the end of March, rainfall totals for the 1994-95 rainy season were 142 and 155 percent of normal for Redwood City and Palo Alto, respectively (National Weather Service, written commun., 1995).

Water levels in wells generally were highest in the spring and lowest in the late summer and early autumn during the study period (fig. 6). This pattern in water levels reflects the pumping pattern in the study area. Because ground-water use primarily is for irrigation, pumping is highest from May through October when irrigation demand is the greatest. An example of the areal distribution of seasonal water-level change between October 6, 1994, and March 30, 1995, is shown in figure 7. The greatest increases in static water level occurred in parts of the $\mathrm{W}$ and $\mathrm{E}$ subareas closest to the consolidated rock contact. Other areas displaying relatively large water-level changes coincide with institutional wells in the $\mathrm{E}$ and $\mathrm{N}$ subareas. The smallest water-level changes occurred in parts of the $\mathrm{N}$ subarea closest to San Francisco Bay and in the central part of the W subarea.

Generalized hydraulic head contours for March 30,1995 , are shown in figure 8 . The screened intervals of wells with perforation data extend, on average, over the 60 - to $180-\mathrm{ft}$ depth range; therefore, water levels 


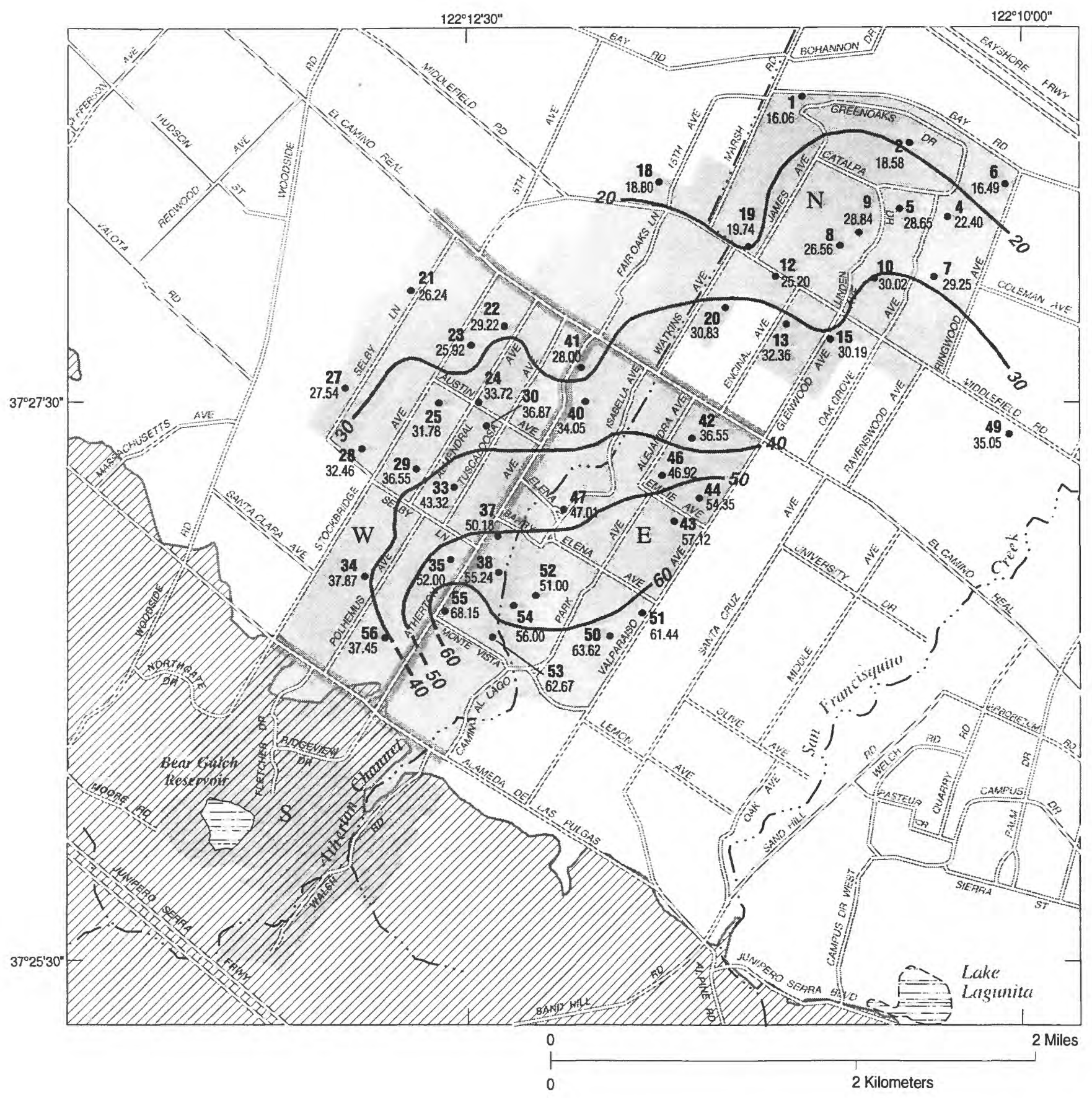

EXPLANATION
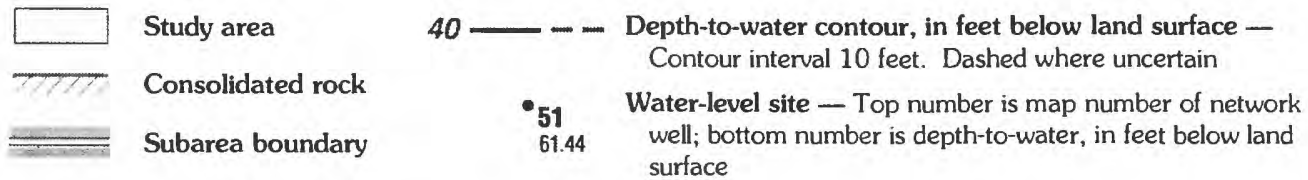

Figure 5. Average depth-to-water in Atherton, California, March 30, 1995. 


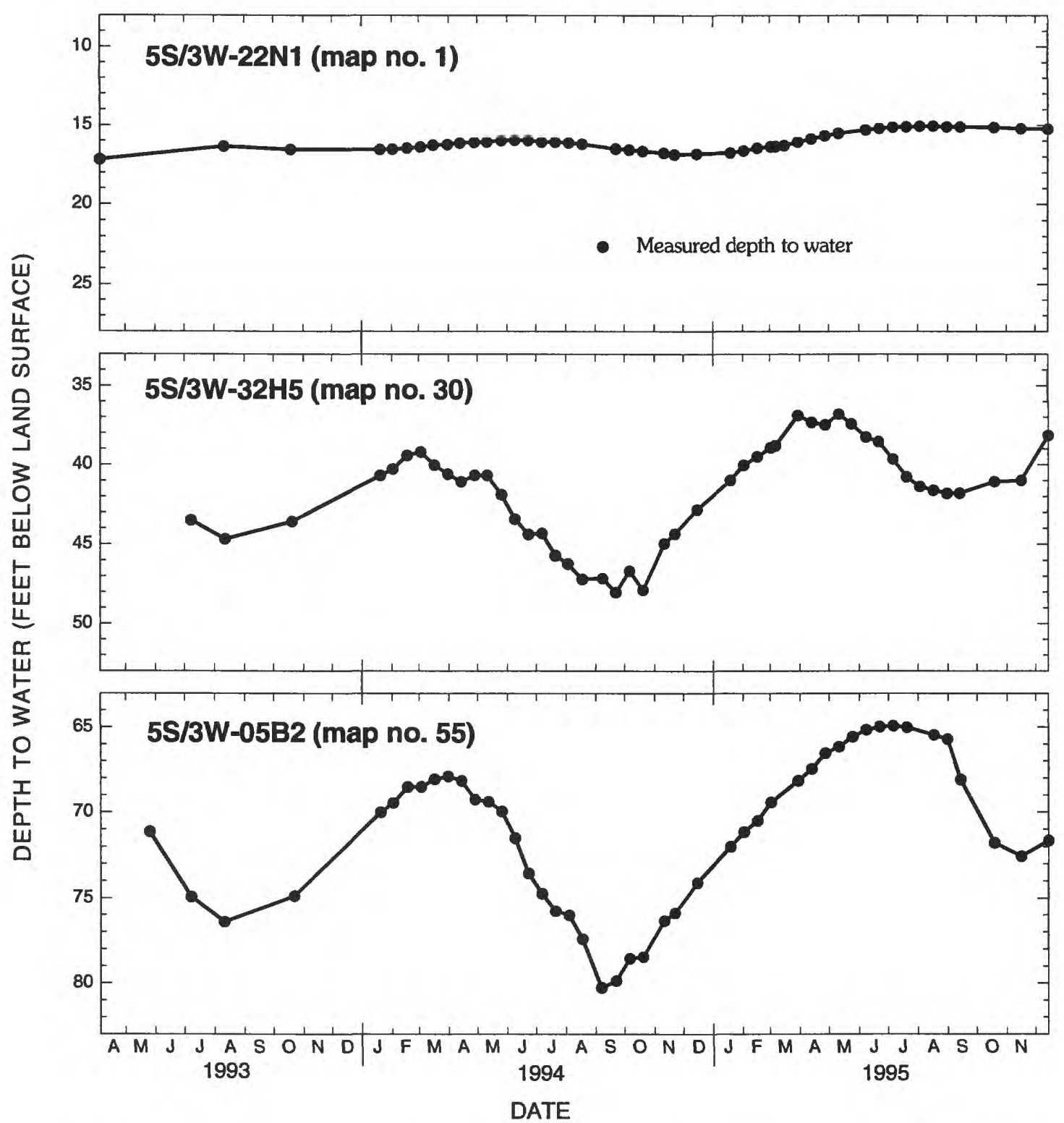

Figure 6. Depth to water levels in selected wells in Atherton, California, April 1993 through December 1995. (See figure 5 for well locations.)

represent average heads within the borehole. In the $\mathrm{N}$ subarea, hydraulic heads range from less than 10 to more than $20 \mathrm{ft}$ above sea level. Hydraulic-head contours in this subarea generally mimic land-surface topography, but with shallower slopes. Ground-water flow is generally northward toward the bay and away from San Francisquito Creek. In contrast, hydraulichead contours in the W subarea do not mimic landsurface elevation. The horizontal component of flow in the W subarea is northward and eastward away from the S subarea. Hydraulic heads range from about 20 to more than $45 \mathrm{ft}$ above sea level with one well (no. 56, fig. 8) having a head value in excess of $60 \mathrm{ft}$ above sea level. The E subarea seems to be a transitional zone that shares the features of the $\mathrm{N}$ and $\mathrm{W}$ subareas. All measured hydraulic heads in the study area were above sea level from April 1993 through September 1995; this head distribution indicates that saltwater intrusion was unlikely during this period. 


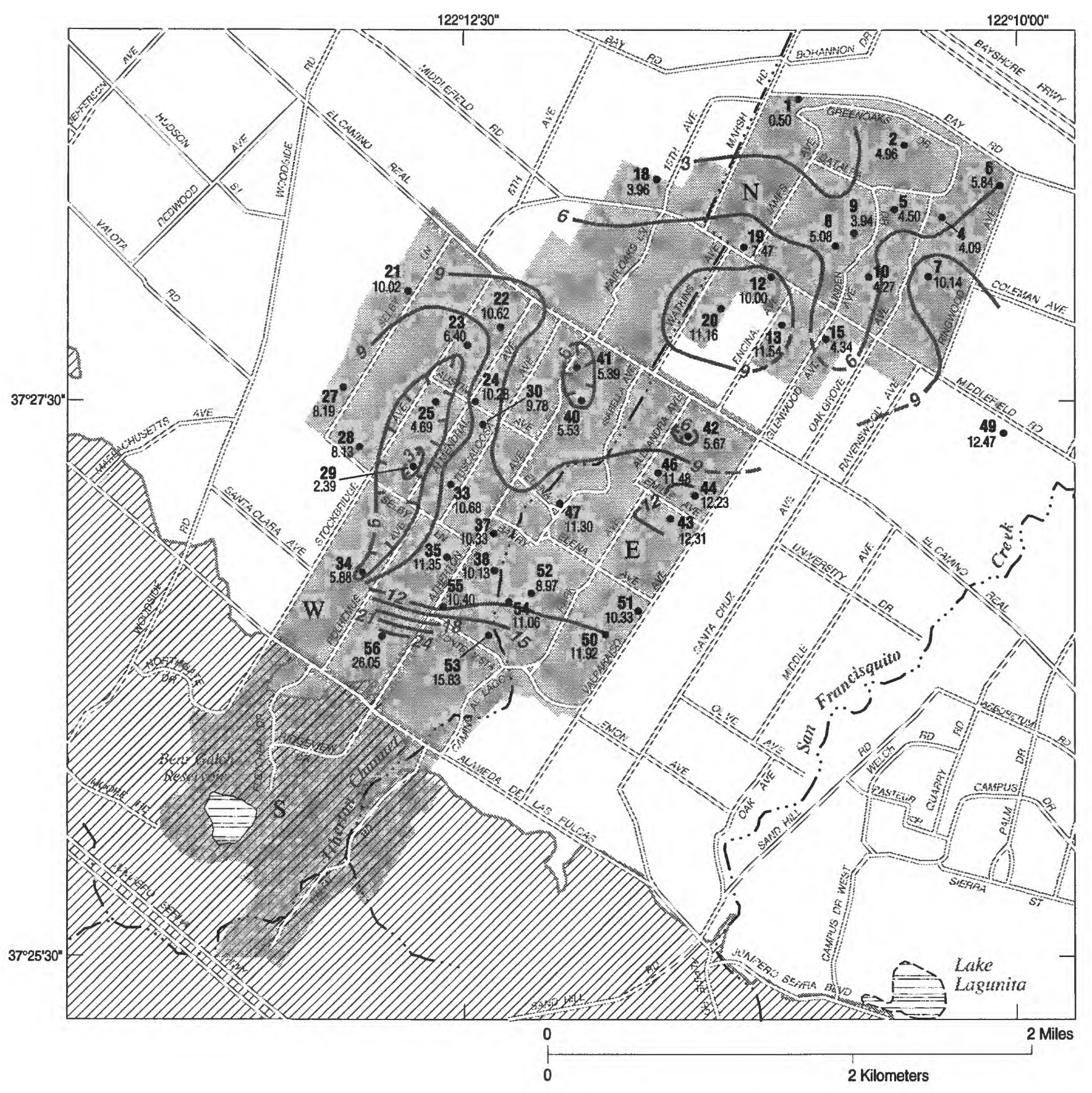

EXPLANATION
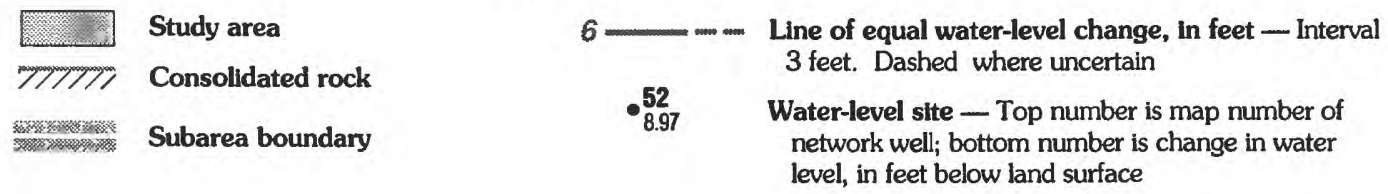

Figure 7. Change in water levels in Atherton, California, between October 6, 1994, and March 30, 1995. 


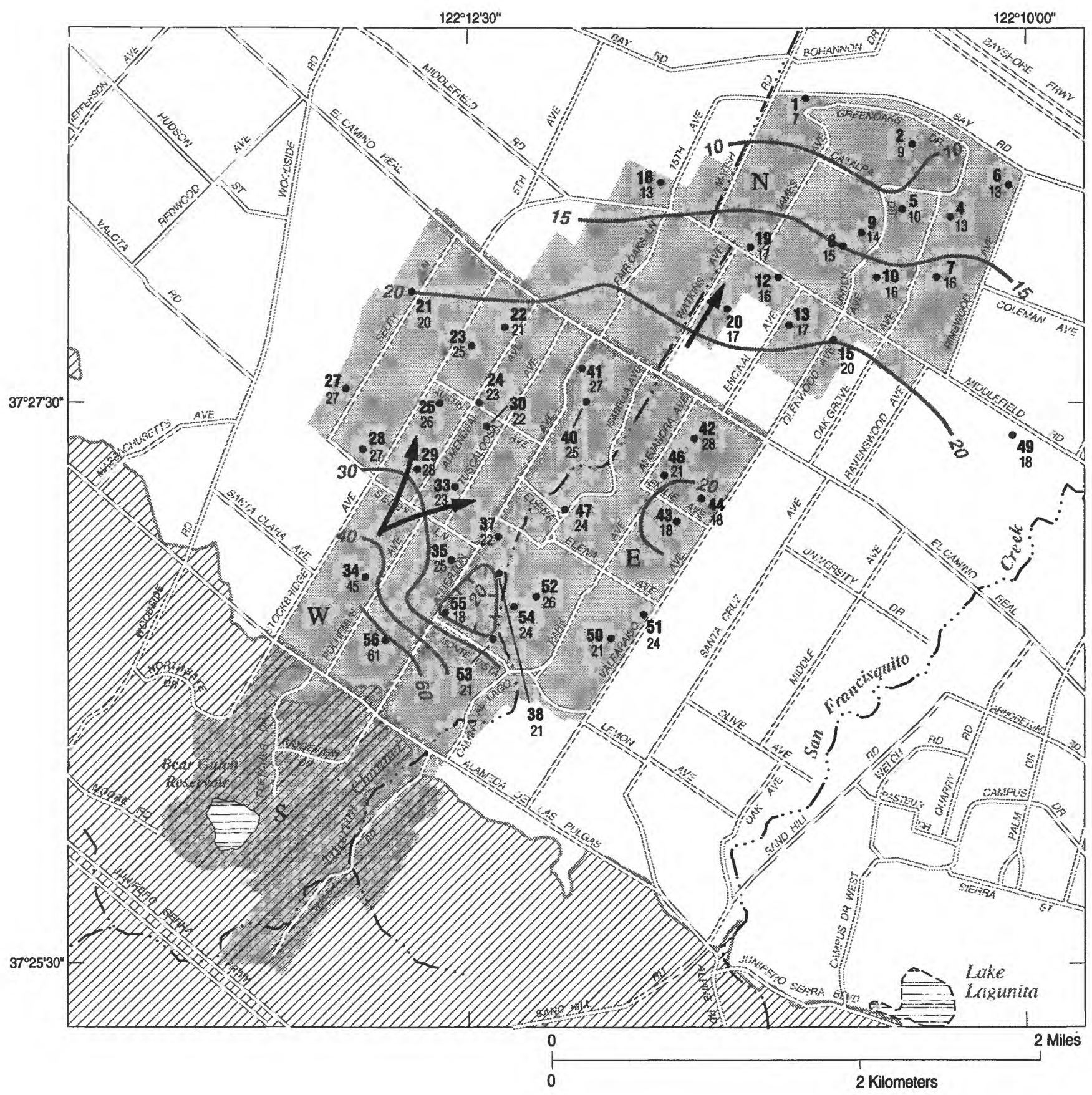

EXPLANATION

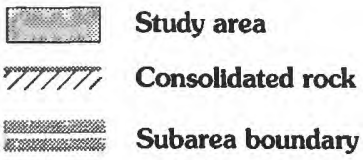

40 Hydraulic head contour, in feet above sea level Contour interval, in feet, is variable

- ${ }_{21}^{38}$ Water-level site - Top number is map number of network well; bottom number is hydraulic head, in feet above sea level

$\rightarrow$ Direction of ground-water flow

Figure 8. Generalized hydraulic head in Atherton, California, March 30, 1995. 


\section{GROUND-WATER QUALITY}

Chemical analyses of well-water samples collected in October 1993 are reported in appendix B. Results were analyzed using a trilinear diagram. A trilinear diagram shows the relative proportions of the most common cations and anions for comparison and classification of water samples independent of total concentration (Hem, 1985). Water samples having the same composition, but different overall concentrations, will plot at the same location on a trilinear diagram. Most well-water chemistry samples may be classified as calcium magnesium carbonate bicarbonate waters. The trilinear diagram indicates that calcium and magnesium constitute more than 50 percent of the cations in 13 of the 20 samples; carbonate and bicarbonate constitute the greatest proportion of anions in $\mathbf{1 7}$ of the 20 samples (fig. 9).

Linear regression of water-quality data from the study area indicates that dissolved solids in ground water are correlated to electrical conductivity of water (EC) (TDS $[\mathrm{mg} / \mathrm{L}]=0.617 \mathrm{EC}[\mu \mathrm{S} / \mathrm{cm}]-15.8 ; \mathrm{r}=0.99$ ). The general salinity of ground water, as indicated by the dissolved-solids concentration of well-water quality samples, indicates that salinity is variable within the study area, ranging from less than $500 \mathrm{mg} / \mathrm{L}$ to almost $1,200 \mathrm{mg} / \mathrm{L}$ (fig. 10). Samples having dissolved-solids concentrations less than $600 \mathrm{mg} / \mathrm{L}$ were measured in the E subarea (wells 47 and 50) and in the southern part of the N subarea (wells 5, 13, and 20). Two of the highest dissolved-solids concentrations were measured in wells 34 and 53 (1,170 and $927 \mathrm{mg} / \mathrm{L}$, respectively), indicating that ground water in areas near the S subarea is slightly saline. Consolidated rock in the study area is of predominantly marine origin and can contain salts of the original connate water that may be the source of these higher dissolved solids. In contrast, bay water may be the source of slightly saline ground water in parts of the N subarea. Dissolved-solids concentrations in samples from wells 1 and 4 were measured at 1,020 and $987 \mathrm{mg} / \mathrm{L}$, respectively. These dissolvedsolids concentrations, however, are far less than those reported by Iwamura (1980) for San Francisco Bay water (about $35,000 \mathrm{mg} / \mathrm{L}$ ) and shallow aquifer samples for the area of the Palo Alto bayfront immediately east of the Bayshore Freeway, Highway 101 (less than 10,000 to greater than $82,000 \mathrm{mg} / \mathrm{L}$ ). Analyses of ground water for stable isotopes of hydrogen and oxy- gen and bromide would help identify the sources of the high dissolved solids in these areas.

The concentrations of sodium in well-water samples ranged from 46 to $200 \mathrm{mg} / \mathrm{L}$, and concentrations of chloride ranged from 62 to $330 \mathrm{mg} / \mathrm{L}$. Hardness for the 20 wells sampled averaged $471 \mathrm{mg} / \mathrm{L}$ as $\mathrm{CaCO}_{3}$ and exceeded the $180-\mathrm{mg} / \mathrm{L}$ minimum value for water to be classified as very hard (Hem, 1985). Irrigation of certain plants with well water high in dissolved solids may cause landscape damage. For example, crops such as apricots, citrus, and plum may be subject to foliar injury from sprinkler irrigation with waters having sodium concentrations as low as $115 \mathrm{mg} / \mathrm{L}$ and chloride concentrations as low as about $180 \mathrm{mg} / \mathrm{L}$ (Ayers and Westcot, 1985). The sodium and chloride concentrations, respectively, in water from wells $1(130 \mathrm{mg} / \mathrm{L}$; $160 \mathrm{mg} / \mathrm{L}), 4$ (110 mg/L; $130 \mathrm{mg} / \mathrm{L}) ; 7$ (120 mg/L; 160 $\mathrm{mg} / \mathrm{L}) ; 34$ (200 mg/L; $330 \mathrm{mg} / \mathrm{L})$; and 53 (150 mg/L; $240 \mathrm{mg} / \mathrm{L}$ ) may cause leaf burn, premature leaf drop, stem dieback, and even death. The calcium and magnesium concentrations in the water samples can be considered likely causes of irrigation-pipe scaling, encrustation of concrete surfaces, and water spotting of plant leaves. These constituents can be beneficial for irrigation in some circumstances because they cause fine soil particles to aggregate, thereby increasing the infiltration capability of water to the soil (Harris, 1991).

Additional constituents of concern include nitrate-nitrogen $\left(\mathrm{NO}_{2}+\mathrm{NO}_{3}\right.$ dissolved as $\left.\mathrm{N}\right)$. Possible anthropogenic sources of nitrate in ground water include fertilizers used for landscaping and leakage from underground sewers (Phillips and others, 1993). One ground-water sample (well 18) showed a nitratenitrogen concentration of $12 \mathrm{mg} / \mathrm{L}$, which exceeds the primary maximum contaminant level (MCL, $10 \mathrm{mg} / \mathrm{L}$ ) set by the California Department of Health Services and the U.S. Environmental Protection Agency for drinking water (California Department of Water Resources, 1995). Nitrate-nitrogen concentrations in drinking water above $10 \mathrm{mg} / \mathrm{L}$ are considered hazardous and may result in methemoglobinemia (blue-baby syndrome) for small children (Hem, 1985). However, the wide range of nitrate-nitrogen concentrations indicates no discernable pattern of areal distribution or well depth. 


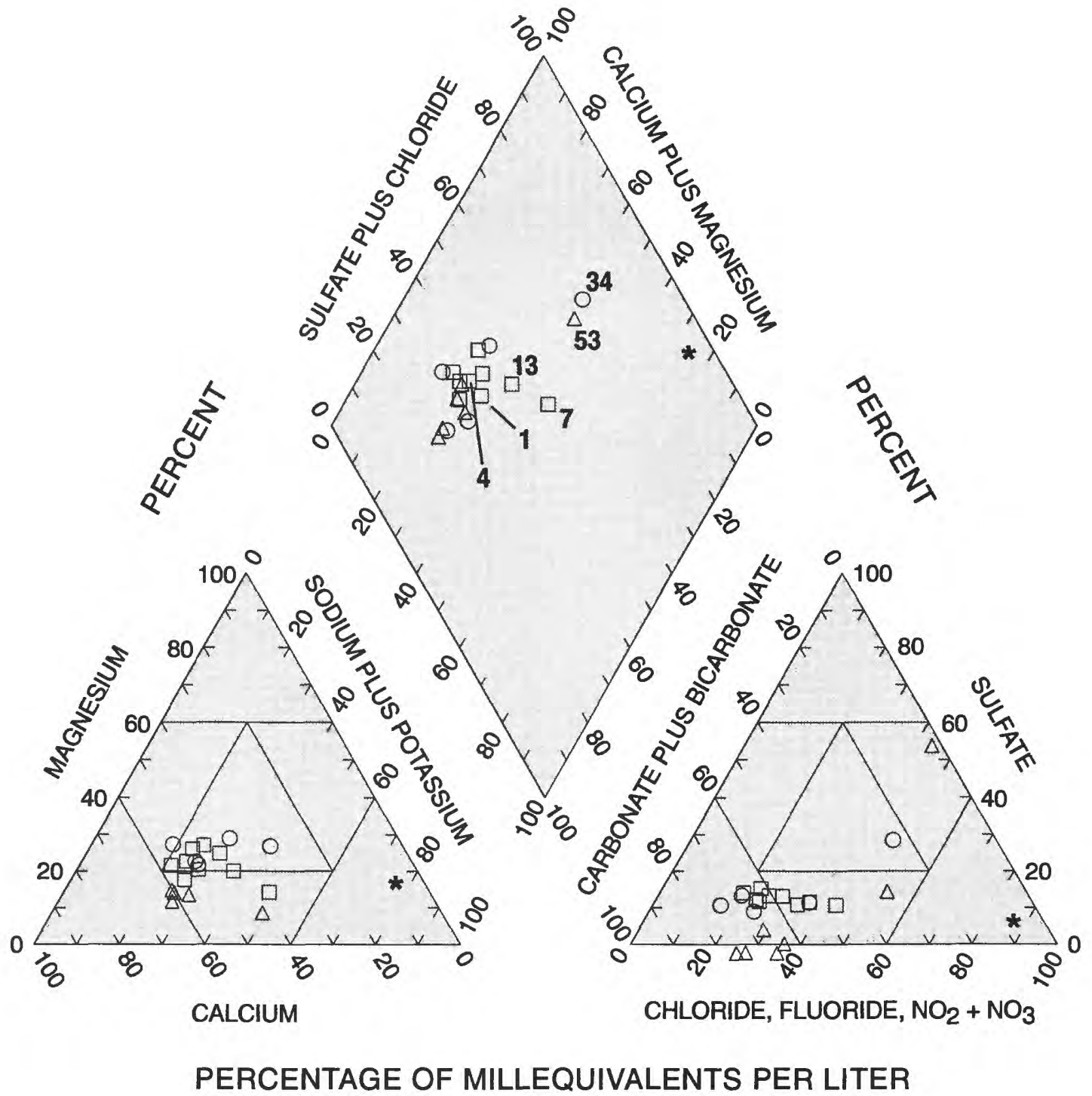

\section{EXPLANATION}

Subarea sites - Numbered well samples discussed in text
O Western
$\square \quad$ Northern
$\triangle$ Eastern

* San Francisco Bay water (Iwamura, 1980)

Figure 9. Characteristics of well-water quality samples in Atherton, California, October 1993. 


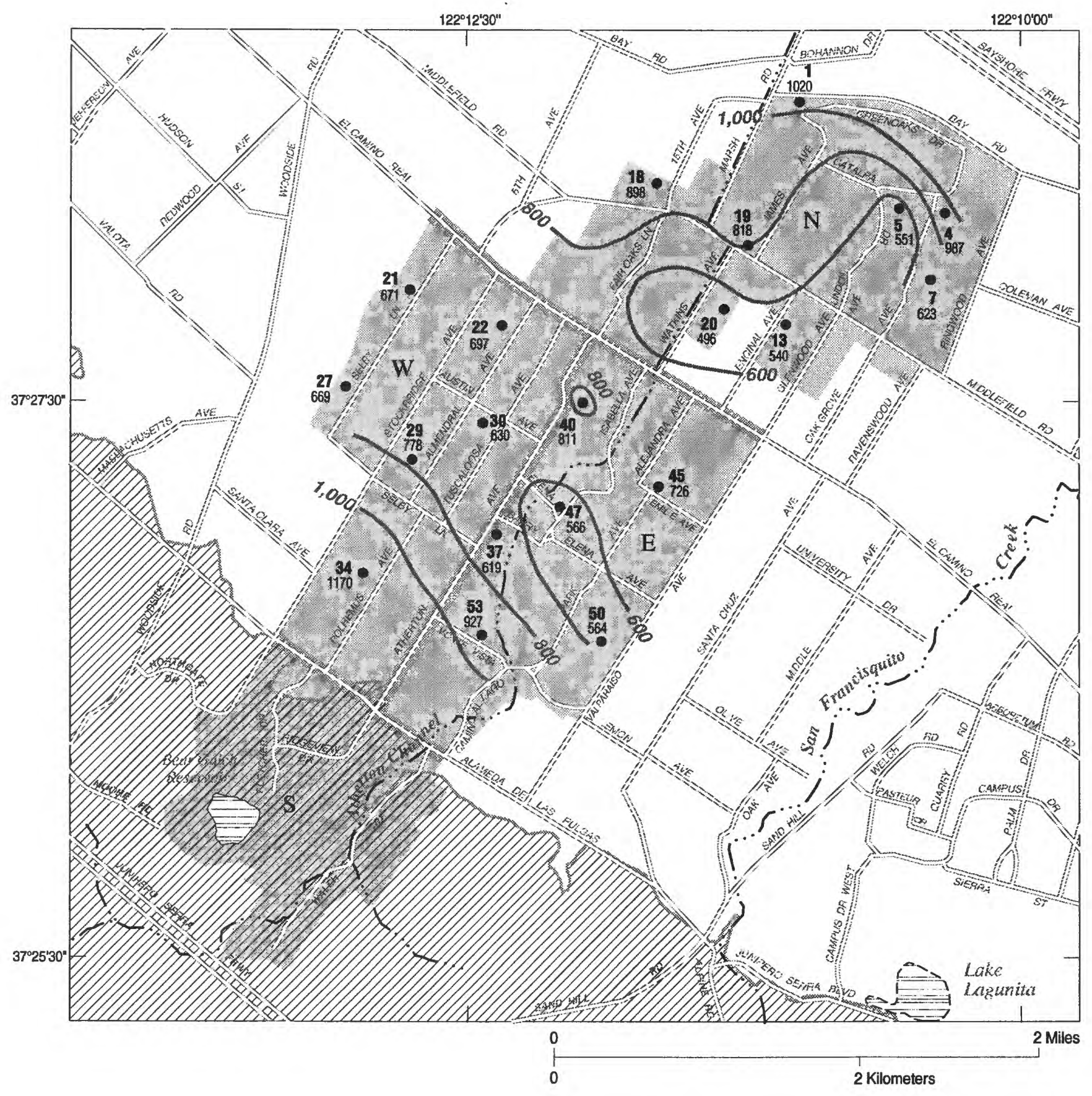

EXPLANATION

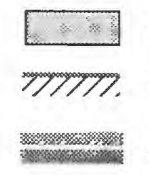

Study area

Consolidated rock

Subarea boundary

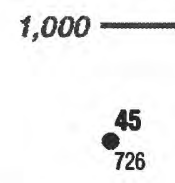

Line of equal dissolved-solids

concentration-Interval, in milligrams per liter

Water-quality site-Top number is map number of network well; bottom number is dissolved-solids concentration, in milligrams per liter

Figure 10. Dissolved-solids concentration of ground water in Atherton, California, October 1993. 
Secondary MCL drinking water standards that apply to the aesthetic concerns of taste, odor, and appearance were exceeded for several constituents. Dissolved solids exceeded the 500-mg/L Federal secondary MCL for drinking water at all wells except well 20 , and chloride and sulfate exceeded the $250-\mathrm{mg} / \mathrm{L}$ MCL only at well 34 (California Department of Water Resources, 1995). None of the constituents that exceeded drinking water standards, nor any constituents reported in appendix B, are regulated for irrigation.

\section{LAND-SURFACE ELEVATION}

The installation of more than 100 private wells in the study area during the 1987-92 drought raised con- cerns that increased ground-water pumping could cause local land subsidence; historically, damage from ground-water overdraft has occurred in adjacent areas. Periods of low rainfall and low recharge, in combination with high pumpage, were accompanied by land subsidence of nearly $13 \mathrm{ft}$ between 1916-67 in the San Jose area, $20 \mathrm{mi}$ southeast of the study area (Poland and Ireland, 1988). The costs associated with this subsidence have amounted to millions of dollars to repair roads, buildings, and sewer lines and to realign canals and reinforce levees along San Francisco Bay (Pewe, 1990). In the late 1930's and early 1940's, failed well casings near what is now the Port of Redwood City indicated possible subsidence several miles northeast of the study area (Poland and Garrett, 1943). Also, land-elevation surveying data for the area north of Palo Alto showed subsidence from 1934 to 1967 (Poland

Table 3. Site descriptions and elevations in Atherton, California, March 1994

(NGS, National Geodetic Survey; ft, foot)

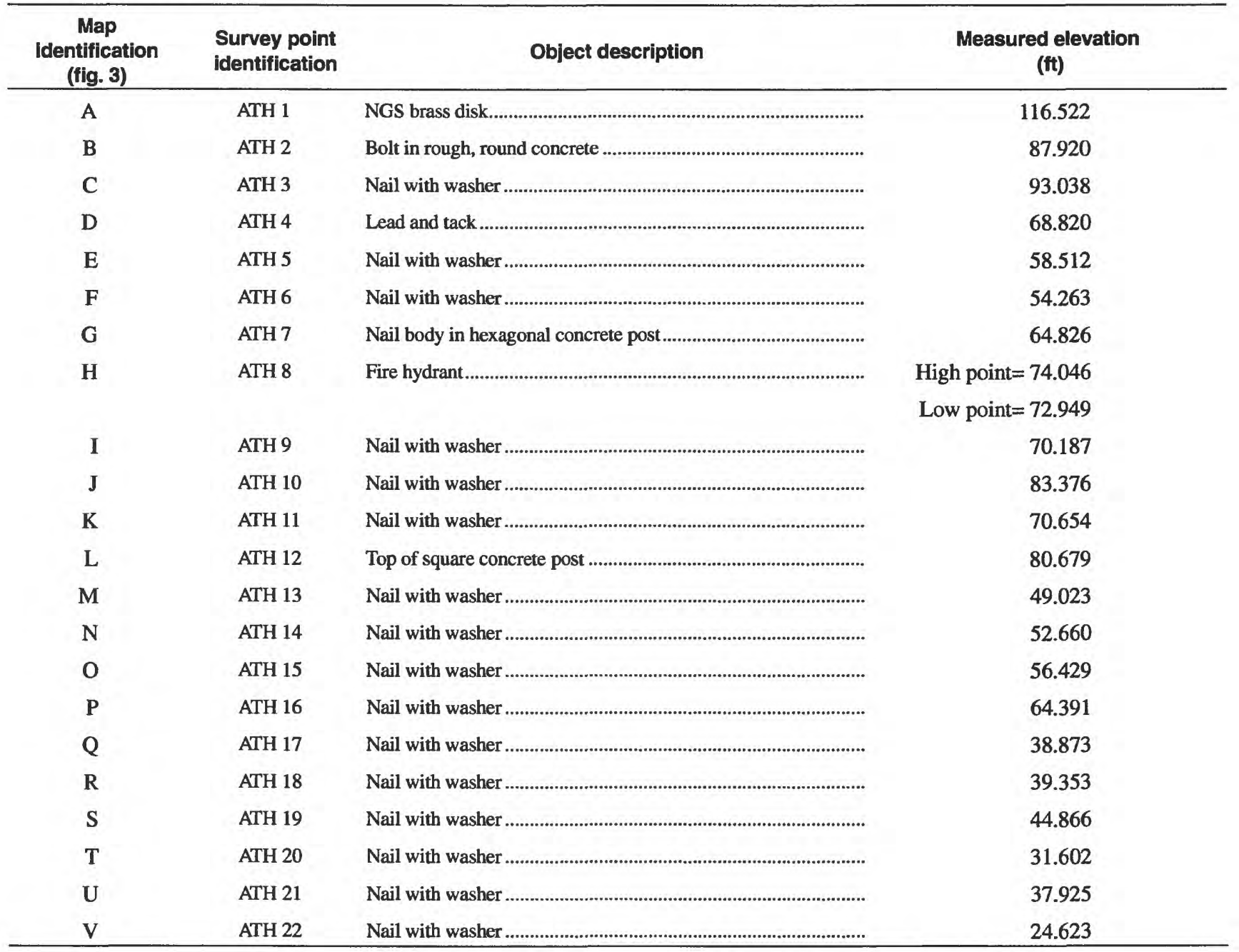


and Ireland, 1988) that ranged from 0.1 to approximately $0.5 \mathrm{ft}$ in the vicinity of the study area.

The lack of a land-elevation surveying network and historical data prompted the establishment of 21 surveying sites as part of this study. These locations, plus one existing bench mark (labeled A on fig. 3), were surveyed in March 1994 to establish a baseline for monitoring future subsidence. Measurements from these sites, described in table 3, generally agree with contoured elevations from the USGS 7 1/2-minute topographic map for the Palo Alto quadrangle (1961, photo revised 1968, 1973, contour interval $5 \mathrm{ft}$ ). However, because of the \pm 2.5 -ft contour interval error of the topographic map, a determination could not be made as to whether subsidence less than this error has occurred since 1961.

Periodic measurements of land-surface elevation (every 5 years) are necessary to detect potential subsidence that may result from aquifer dewatering and the compaction of fine-grained sediment beds. Continuous or at least periodic (semiannual) water-level measurements can serve as a good interim means of monitoring potential aquifer dewatering between land-elevation surveying efforts. In addition to the 22 land-elevation surveying sites, future surveying should include the 9 assumed active institutional wells, which were mostly inaccessible for the March 1994 survey, but where any ongoing subsidence would be expected to be most evident.

\section{SUMMARY AND CONCLUSIONS}

Ground-water conditions were assessed for an area of the San Francisquito cone coinciding with the boundary of the town of Atherton. This was done using estimates of annual pumpage, lithologic and geologic data from well-driller logs and previously published reports and maps, measured water levels in wells, chemical analyses from well-water samples, and the establishment of a network of sites for monitoring land subsidence. The results were used to assess pumping effects on ground-water levels and chemistry and to establish the framework for future monitoring of geohydrologic conditions.

The San Francisquito cone is a semiconfined aquifer composed of discontinuous lenses of unconsolidated coarse- and fine-grained sediments of Pleistocene and Holocene age. Lithologic logs and geologic literature for the area indicate that coarse-grained deposits are identified in greatest abundance in upslope areas closest to the consolidated rock/alluvium boundary and adjacent to both present-day and ancient stream channels. Sediments become progressively finer grained toward San Francisco Bay. Because finegrained sediments are more compressible than coarsegrained sediments, downslope areas of the San Francisquito cone, including the $\mathrm{N}$ subarea and adjacent parts of the E subarea, are more susceptible to land subsidence. Lowering the water table through pumpage and(or) drought reduces the water's buoyancy on the overlying sediments. This results in lowering of land surface because of sediment compaction and a reduction in ground-water storage capacity.

Recharge, in conjunction with discharge, governs the overall condition of the aquifer system. Recharge to the San Francisquito cone has been reported to be approximately 3,000 acre-ft/yr, typically as percolation of storm runoff from upslope areas of the San Francisquito Creek drainage basin. Additional sources of recharge include area lakes and reservoirs, infiltration of precipitation and(or) irrigation water, and leakage from water mains and sewer pipes. Discharge typically occurs from ground-water pumping in downslope areas, evapotranspiration, and seepage of ground water to surface-water features.

Mail surveys, site visits, and miscellaneous reports and paper records indicate that the number of active wells ranges from 175 to 403 . These totals include residential (394) and institutional (9) wells. If inactive and destroyed wells also are counted, a total of 503 wells are known to exist or to have existed previously in the study area. Included in this total are the more than 100 wells installed during the drought period of 1987-92.

Estimates of total residential and institutional ground-water pumpage in the study area were made using data from wells with inline flowmeters and(or) time-totalizer and Doppler meter-measured flow rates during April 1993 through September 1995. Annual pumpage for 269 assumed active residential wells was estimated to be about 510 acre-ft/yr versus an estimated total pumpage of about 200 acre-ft/yr by 9 assumed active institutional wells. The combined total of residential and institutional pumpage (710 acre-ft/ yr) represents 19 percent of the estimated total annual water supply. Considerable uncertainty in well pumping rates of residential and institutional wells and the number of active wells limits a more reliable estimation of total annual pumpage for the study area. Improved estimates of these pumping rates are needed 
to assess the relation between changes in ground-water storage and pumping from wells in the study area.

Depth-to-water in wells from April 1993 through September 1995 ranged from less than $20 \mathrm{ft}$ in the $\mathrm{N}$ subarea to more than $70 \mathrm{ft}$ in the $\mathrm{E}$ subarea. Seasonal fluctuations of water levels indicate that the shallowest depth-to-water levels occur in the spring, and the greatest depth-to-water levels generally occur in late summer and early autumn toward the end of the irrigation season. Mapping water levels with respect to sea level (hydraulic head) reveals differences in flow direction between the $\mathrm{N}, \mathrm{W}$, and $\mathrm{E}$ subareas. In the $\mathrm{N}$ subarea, hydraulic heads range from less than 10 to more than $20 \mathrm{ft}$ above sea level, and hydraulic-head contours indicate that ground-water flow in this subarea is northward toward the bay and away from San Francisquito Creek. In the W subarea, hydraulic heads range from 20 to more than $45 \mathrm{ft}$ above sea level and show the ground-water flow to be from the S subarea toward the northeast. All measured hydraulic heads within the study area from April 1993 through September 1995 were above sea level; this head distribution indicates that saltwater intrusion was unlikely during this period.

Most well-water samples are classified as calcium magnesium carbonate bicarbonate waters. A trilinear diagram indicates that calcium and magnesium constitute more than 50 percent of the cations in 13 of the 20 samples; carbonate and bicarbonate constitute the greatest proportion of anions in 17 of the 20 samples. Ground water in most of the study area has dissolved-solids concentrations greater than $600 \mathrm{mg} / \mathrm{L}$. Dissolved-solids concentrations were less than 600 $\mathrm{mg} / \mathrm{L}$ in samples from two wells in the E subarea and from three wells in the southern part of the $\mathrm{N}$ subarea. Two areas of dissolved-solids concentrations exceeding $1,000 \mathrm{mg} / \mathrm{L}$ were defined by several wells at opposite ends of the study area. One well each in the $\mathrm{W}$ and E subareas indicates the presence of slightly saline ground water in areas near the S subarea. This saline water may be the result of upconing connate water associated with marine deposits of the S subarea. Two N subarea wells nearest San Francisco Bay also had dissolved-solids concentrations approaching or greater than $1,000 \mathrm{mg} / \mathrm{L}$. This salinity level, although far below dissolved-solids concentrations reported for San Francisco Bay water $(35,000 \mathrm{mg} / \mathrm{L})$ and the shallow aquifers of the Palo Alto Baylands (less than 10,000 to more than $82,000 \mathrm{mg} / \mathrm{L}$ ), indicates that this part of the study area may have been degraded by saltwater intrusion. The high sodium and chloride concentrations measured in wells $1,4,7,34$, and 53 may cause leaf burn, premature leaf drop, stem dieback, and even death if ground water from these wells is used for irrigation.

Nitrate as nitrate-nitrogen was measured at a concentration of $12 \mathrm{mg} / \mathrm{L}$ at one well, which is in excess of the $10-\mathrm{mg} / \mathrm{L}$ primary MCL for drinking water and the level where small children may develop methemoglobinemia (blue-baby syndrome). Aesthetic concerns of taste, odor, and appearance were measured to be in excess of secondary MCL drinking water standards for total dissolved solids at all wells sampled and for chloride and sulfate at one well each. Water hardness, which at high levels causes scaling of irrigation pipes and encrustation of concrete surfaces, averaged $471 \mathrm{mg} / \mathrm{L}$ as $\mathrm{CaCO}_{3}$ for the 20 wells sampled. This level is substantially more than the $180-\mathrm{mg} / \mathrm{L} \mathrm{mini-}$ mum value for water to be classified as very hard.

Understanding the effects that ground-water pumping can have on an aquifer system requires examining both potential land subsidence, as manifested by land-surface elevation changes, and water-level conditions. The consequences of excessive ground-water pumping from an aquifer containing compressible, fine-grained deposits can include serious damage to surface and underground infrastructure and a reduction in the quantity of aquifer water. Concern over subsidence has a historical basis in the form of welldocumented damage from ground-water overdraft in adjacent areas, most notably in the San Jose area, which experienced nearly $13 \mathrm{ft}$ of subsidence between 1916-67. Limited historical data for the study area indicate that 0.1 to approximately $0.5 \mathrm{ft}$ of subsidence occurred during 1934-67. Land-surface elevation measurements from a network of 22 sites surveyed in March 1994 could not be used to determine if subsidence is presently occurring, but they do provide a baseline with which future surveying efforts can be compared. To determine if subsidence is presently occurring or will occur in the future requires repetitive measurements of land-surface elevation, perhaps as frequently as every 5 years, in combination with at least periodic ground-water-level monitoring. Future surveying efforts should include the nine assumed active institutional wells where any subsidence would be most evident. 


\section{REFERENCES}

Ayers, R.S., and Westcot, D.W., 1985, Water quality for agriculture: United Nations Food and Agriculture Organization, Paper 29, Rev. 1, 174 p.

Belitz, Kenneth, and Heimes, F.J., 1990, Character and evolution of the ground-water flow system in the central part of the western San Joaquin Valley, California: U.S. Geological Survey Water-Supply Paper 2348, 28 p.

California Department of Water Resources, 1967, Evaluation of ground-water resources, south San Francisco Bay, Appendix A: Geology: Bulletin 118-1, 153 p. 1995, Compilation of Federal and State drinking water standards and criteria: Quality Assurance Technical Document 3, 53 p.

Clark, W.O., 1924, Ground water in Santa Clara Valley, California: U.S. Geological Survey Water-Supply Paper $519,209 \mathrm{p}$.

Fio, J.L., and Leighton, D.A., 1995, Geohydrologic framework, historical development of the ground-water system, and general hydrologic and water-quality conditions in 1990, south San Francisco Bay and peninsula area, California: U.S. Geological Survey OpenFile Report 94-357, 46 p.

Fishman, M.J., and Friedman, L.C., eds., 1989, Methods for determination of inorganic substances in water and fluvial sediments: U.S. Geological Survey Techniques of Water-Resources Investigations, book 5, chap. A1, $545 \mathrm{p}$.

Harris, D.C., 1991, Quantitative chemical analysis: New York, W.H. Freeman Company, 782 p.

Hem, J.D., 1985, Study and interpretation of the chemical characteristics of natural water: U.S. Geological Survey Water-Supply Paper 2254, 263 p.

Iwamura, T.I., 1980, Saltwater intrusion investigation in the Santa Clara County baylands area, California: Santa Clara Valley Water District, 115 p.

Lee, C.H., 1923-25, Wells and water levels in Atherton and Menlo Park pumping district: U.C. Berkeley Water Resources Center Archives, 1 envelope. 1924-26, Water supply in Atherton and Menlo Park pumping district: U.C. Berkeley Water Resources Center Archives, notes, diagram, and reports, 1 envelope. 1925, Report on water supply for property of E.S. Heller at Atherton: U.C. Berkeley Water Resources Center Archives, v. 2, 28 p.
Leighton, D.A., Fio, J.L., and Metzger, L.F., 1995, Database of well and areal data, south San Francisco Bay and Peninsula area, California: U.S. Geological Survey Water-Resources Investigations Report 94-4151, $47 \mathrm{p}$.

Pampeyan, E.H., 1993, Geologic map of the Palo Alto and part of the Redwood Point 7-1/2 quadrangles, San Mateo and Santa Clara Counties: U.S. Geological Survey Miscellaneous Investigations Series Map I-2371.

Pewe, T.L., 1990, Land subsidence and earth-fissure formation caused by groundwater withdrawal in Arizona--a review: Geological Society of America, Special Paper 252, p. 219-233.

Phillips, S.P., Hamlin, S.N., and Yates, E.B., 1993, Geohydrology, water quality, and estimation of ground-water recharge in San Francisco, California, 1987-92: U.S. Geological Survey Water-Resources Investigations Report 93-4019, 69 p.

Poland, J.F., and Garrett, A.A., 1943, Ground-water conditions in the Redwood City area, California, with particular reference to water supply for the Pacific Portland Cement Company: U.S. Geological Survey Open-File Report, $12 \mathrm{p}$.

Poland, J.F., and Ireland, R.L., 1988, Land subsidence in the Santa Clara Valley, California, as of 1982: U.S. Geological Survey Professional Paper 497-F, 61 p.

Poulter, A.F., 1934, The organization and operation of the Bear Gulch Water Company: California Water Service Company, 12 p.

Rantz, S.E., 1971, Mean annual precipitation and precipitation depth-duration frequency data for the San Francisco Bay region, California: U.S. Geological Survey Open-File Report, 23 p.

Smith, William, and Mylvaganam, K.S., 1993, Ultrasonic flowmeters: Measurements and Control, v. 27, no. 5, p. 184-191.

Sokol, Daniel, 1964, The hydrogeology of the San Francisquito Creek Basin, San Mateo and Santa Clara Counties, California: Palo Alto, Calif., Stanford University, Ph. D. dissertation, $238 \mathrm{p}$.

U.S. Army Corps of Engineers, 1972, Survey report on San Francisquito Creek, San Mateo and Santa Clara Counties, California for flood control and allied purposes: U.S. Army Engineer District, San Francisco, Calif., $27 \mathrm{p}$.

Wood, W.W., 1976, Guidelines for collection and field analysis of ground-water samples for selected unstable constituents: U.S. Geological Survey Techniques of WaterResources Investigations, book 1, chap. D2, 24 p. 


\section{APPENDIX}


Appendix A. Site identification, location, construction, and measurements of average depth to water for network wells in Atherton, California

[Map no.: network well site. Site identification No.: Unique number for each well based on township and range. Latitude/longitude: Well coordinates in degrees-minutes-seconds. Total depth: Distance below land surface in feet. Depth of perforated interval: Location of well screen with respect to land surface, in feet. Land-surface elevation: Elevation of land surface at well site with respect to sea level determined to an accuracy of \pm 2.5 feet from USGS Palo Alto 7 1/2 minute quadrangle. Depth to water and hydraulic head measurements are from March 30, 1995. Average depth-to-water: Average depth to water level in feet during April 1993 to September 1995. na = information not available; ft, foot. Values are shown on figure 5]

\begin{tabular}{|c|c|c|c|c|c|c|c|c|c|}
\hline $\begin{array}{c}\text { Map no. } \\
\text { (fig. 3) }\end{array}$ & $\begin{array}{l}\text { Site } \\
\text { identifi- } \\
\text { cation }\end{array}$ & Latitude & Longitude & $\begin{array}{l}\text { Total } \\
\text { depth }\end{array}$ & $\begin{array}{l}\text { Depth of } \\
\text { perforated } \\
\text { interval }\end{array}$ & $\begin{array}{l}\text { Land- } \\
\text { surface } \\
\text { elevation }\end{array}$ & $\begin{array}{l}\text { Depth } \\
\text { to } \\
\text { water }\end{array}$ & $\begin{array}{c}\text { Hydraulic } \\
\text { head } \\
\text { (rounded) }\end{array}$ & $\begin{array}{l}\text { Average } \\
\text { depth } \\
\text { to water }\end{array}$ \\
\hline 1 & $5 \mathrm{~S} / 3 \mathrm{~W}-22 \mathrm{~N} 1$ & $37^{\circ} 28^{\prime} 35^{\prime \prime}$ & $122^{\circ} 11^{\prime} 00^{\prime \prime}$ & $1_{\text {na }}$ & na & 23 & 16.06 & 7 & 16.23 \\
\hline 2 & $-27 \mathrm{~B} 2$ & $37^{\circ} 28^{\prime} 25^{\prime \prime}$ & $122^{\circ} 10^{\prime} 31^{\prime \prime}$ & 130 & $20-110$ & 28 & 18.58 & 9 & 21.94 \\
\hline 3 & $-27 \mathrm{~B} 3$ & $37^{\circ} 28^{\prime} 30^{\prime \prime}$ & $122^{\circ} 10^{\prime} 26^{\prime \prime}$ & 182 & $40-180$ & 22 & na & na & na \\
\hline 4 & $-27 G 1$ & $37^{\circ} 28^{\prime} 09^{\prime \prime}$ & $122^{\circ} 10^{\prime} 21^{\prime \prime}$ & 65 & $38-58$ & 35 & 22.40 & 13 & 24.49 \\
\hline 5 & $-27 G 4$ & $37^{\circ} 28^{\prime} 11^{\prime \prime}$ & $122^{\circ} 10^{\prime} 34^{\prime \prime}$ & 140 & $60-120$ & 39 & 28.65 & 10 & 31.00 \\
\hline 6 & $-27 \mathrm{H} 5$ & $37^{\circ} 28^{\prime} 16^{\prime \prime}$ & $122^{\circ} 10^{\prime} 05^{\prime \prime}$ & 115 & $60-100$ & 30 & 16.49 & 13 & 19.69 \\
\hline 7 & $-27 \mathrm{~K} 2$ & $37^{\circ} 27^{\prime} 56^{\prime \prime}$ & $122^{\circ} 10^{\prime} 25^{\prime \prime}$ & 300 & $145-280$ & 45 & 29.25 & 16 & 33.59 \\
\hline 8 & $-27 \mathrm{~L} 3$ & $37^{\circ} 28^{\prime} 03^{\prime \prime}$ & $122^{\circ} 10^{\prime} 50^{\prime \prime}$ & 180 & $60-180$ & 42 & 26.56 & 15 & 29.37 \\
\hline 9 & $-27 \mathrm{~L} 4$ & $37^{\circ} 28^{\prime} 06^{\prime \prime}$ & $122^{\circ} 10^{\prime} 45^{\prime \prime}$ & 140 & $60-120$ & 42 & 28.84 & 14 & 30.90 \\
\hline 10 & $-27 L 6$ & $37^{\circ} 27^{\prime} 56^{\prime \prime}$ & $122^{\circ} 10^{\prime} 41^{\prime \prime}$ & 180 & $50-180$ & 46 & 30.02 & 16 & 32.10 \\
\hline 11 & ${ }^{2}-27 \mathrm{~L}_{-}$ & $37^{\circ} 28^{\prime} 05^{\prime \prime}$ & $122^{\circ} 10^{\prime} 44^{\prime \prime}$ & na & na & 43 & na & na & na \\
\hline 12 & $-27 \mathrm{M} 2$ & $37^{\circ} 27^{\prime} 57^{\prime \prime}$ & $122^{\circ} 11^{\prime} 07^{\prime \prime}$ & 200 & $60-200$ & 42 & 25.20 & 16 & ${ }^{3} 29.66$ \\
\hline 13 & $-27 N 1$ & $37^{\circ} 27^{\prime} 45^{\prime \prime}$ & $122^{\circ} 11^{\prime} 05^{\prime \prime}$ & 300 & $70-280$ & 50 & 32.36 & 17 & 37.02 \\
\hline 14 & $-27 N 2$ & $37^{\circ} 27^{\prime} 44^{\prime \prime}$ & $122^{\circ} 11^{\prime} 07^{\prime \prime}$ & 300 & $70-290$ & 51 & na & na & na \\
\hline 15 & $-27 N 5$ & $37^{\circ} 27^{\prime} 43^{\prime \prime}$ & $122^{\circ} 10^{\prime} 53^{\prime \prime}$ & 140 & $50-130$ & 50 & 30.19 & 20 & 32.23 \\
\hline 16 & $-27 Q 1$ & $37^{\circ} 27^{\prime} 46^{\prime \prime}$ & $122^{\circ} 10^{\prime} 24^{\prime \prime}$ & 316 & $163-295$ & 48 & $\mathrm{na}$ & na & na \\
\hline 17 & $-27 Q 4$ & $37^{\circ} 27^{\prime} 48^{\prime \prime}$ & $122^{\circ} 10^{\prime} 29^{\prime \prime}$ & 123 & $20-120$ & 48 & $\mathrm{na}$ & na & na \\
\hline 18 & $-28 \mathrm{G} 1$ & $37^{\circ} 28^{\prime} 17^{\prime \prime}$ & $122^{\circ} 11^{\prime} 39^{\prime \prime}$ & 75 & $35-60$ & 32 & 18.80 & 13 & 21.05 \\
\hline 19 & $-28 \mathrm{~J} 3$ & $37^{\circ} 28^{\prime} 03^{\prime \prime}$ & $122^{\circ} 11^{\prime} 15^{\prime \prime}$ & 150 & na & 37 & 19.74 & 17 & 23.15 \\
\hline 20 & $-28 \mathrm{R} 1$ & $37^{\circ} 27^{\prime} 50^{\prime \prime}$ & $122^{\circ} 11^{\prime \prime 2} 2^{\prime \prime}$ & 280 & $240-280$ & 48 & 30.83 & 17 & 35.45 \\
\hline 21 & $-29 \mathrm{~K} 3$ & $37^{\circ} 27^{\prime} 54^{\prime \prime}$ & $122^{\circ} 12^{\prime} 47^{\prime \prime}$ & 200 & $100-180$ & 46 & 26.24 & 20 & 30.91 \\
\hline 22 & $-29 R 2$ & $37^{\circ} 27^{\prime} 46^{\prime \prime}$ & $122^{\circ} 12^{\prime} 22^{\prime \prime}$ & 250 & $145-205$ & 50 & 29.22 & 21 & 33.91 \\
\hline 23 & $-29 R 3$ & $37^{\circ} 27^{\prime} 42^{\prime \prime}$ & $122^{\circ} 12^{\prime} 31^{\prime \prime}$ & 214 & $103-209$ & 50 & 25.92 & 25 & 29.48 \\
\hline 24 & $-32 \mathrm{~A} 2$ & $37^{\circ} 27^{\prime} 30^{\prime \prime}$ & $122^{\circ} 12^{\prime} 29^{\prime \prime}$ & 220 & $60-220$ & 56 & 33.72 & 23 & 39.08 \\
\hline 25 & $-32 \mathrm{~B} 2$ & $37^{\circ} 27^{\prime} 30^{\prime \prime}$ & $122^{\circ} 12^{\prime} 40^{\prime \prime}$ & $4_{\mathrm{na}}$ & na & 58 & 31.78 & 26 & 34.34 \\
\hline 26 & $-32 \mathrm{C} 4$ & $37^{\circ} 27^{\prime} 36^{\prime \prime}$ & $122^{\circ} 12^{\prime} 49^{\prime \prime}$ & 280 & $60-280$ & 55 & na & na & $5_{37.36}$ \\
\hline 27 & $-32 \mathrm{D} 2$ & $37^{\circ} 27^{\prime} 33^{\prime \prime}$ & $122^{\circ} 13^{\prime} 05^{\prime \prime}$ & 201 & $40-180$ & 54 & 27.54 & 27 & 31.98 \\
\hline 28 & $-32 \mathrm{~F} 4$ & $37^{\circ} 27^{\prime} 20^{\prime \prime}$ & $122^{\circ} 13^{\prime} 01^{\prime \prime}$ & 235 & $40-235$ & 59 & 32.46 & 27 & 37.05 \\
\hline 29 & $-32 \mathrm{G} 2$ & $37^{\circ} 26^{\prime} 16^{\prime \prime}$ & $122^{\circ} 12^{\prime} 46^{\prime \prime}$ & 200 & $20-180$ & 64 & 36.55 & 28 & 37.46 \\
\hline 30 & $-32 \mathrm{H} 5$ & $37^{\circ} 27^{\prime} 25^{\prime \prime}$ & $122^{\circ} 12^{\prime} 27^{\prime \prime}$ & 122 & $80-120$ & 59 & 36.87 & 22 & 41.76 \\
\hline 31 & $-32 \mathrm{~J} 1$ & $37^{\circ} 27^{\prime} 07^{\prime \prime}$ & $122^{\circ} 12^{\prime} 27^{\prime \prime}$ & 220 & $80-200$ & 70 & $\mathrm{na}$ & na & 651.86 \\
\hline
\end{tabular}


Appendix A. Site identification, location, construction, and measurements of average depth to water for network wells in Atherton, California - Continued

\begin{tabular}{|c|c|c|c|c|c|c|c|c|c|}
\hline $\begin{array}{c}\text { Map no. } \\
\text { (fig. 3) }\end{array}$ & $\begin{array}{c}\text { Site } \\
\text { Identifi- } \\
\text { cation }\end{array}$ & Latitude & Longltude & $\begin{array}{l}\text { Total } \\
\text { depth }\end{array}$ & $\begin{array}{l}\text { Depth of } \\
\text { perforated } \\
\text { interval }\end{array}$ & $\begin{array}{c}\text { Land- } \\
\text { surface } \\
\text { elevation }\end{array}$ & $\begin{array}{c}\text { Depth } \\
\text { to } \\
\text { water }\end{array}$ & $\begin{array}{c}\text { Hydraulic } \\
\text { head } \\
\text { (rounded) }\end{array}$ & $\begin{array}{c}\text { Average } \\
\text { depth } \\
\text { to water }\end{array}$ \\
\hline 32 & $-32 \mathrm{~J} 2$ & $37^{\circ} 27^{\prime} 07^{\prime \prime}$ & $122^{\circ} 12^{\prime} 21^{\prime \prime}$ & 200 & $60-180$ & 71 & na & na & ${ }^{7} 53.02$ \\
\hline 33 & $-32 \mathrm{~K} 3$ & $37^{\circ} 27^{\prime} 12^{\prime \prime}$ & $122^{\circ} 12^{\prime} 36^{\prime \prime}$ & 208 & $60-200$ & 66 & 43.32 & 23 & 48.44 \\
\hline 34 & $-32 \mathrm{P} 3$ & $37^{\circ} 26^{\prime} 53^{\prime \prime}$ & $122^{\circ} 13^{\prime} 01^{\prime \prime}$ & 200 & $60-190$ & 83 & 37.87 & 45 & 39.83 \\
\hline 35 & $-32 \mathrm{Q} 4$ & $37^{\circ} 26^{\prime} 56^{\prime \prime}$ & $122^{\circ} 12^{\prime} 37^{\prime \prime}$ & 200 & $60-180$ & 77 & 52.00 & 25 & 57.39 \\
\hline 36 & $5 \mathrm{~S} / 3 \mathrm{~W}-32 \mathrm{Q} 5$ & $37^{\circ} 26^{\prime} 53^{\prime \prime}$ & $122^{\circ} 12^{\prime} 46^{\prime \prime}$ & 200 & $80-180$ & 80 & na & na & na \\
\hline 37 & $-32 R 3$ & $37^{\circ} 27^{\prime} 01^{\prime \prime}$ & $122^{\circ} 12^{\prime} 24^{\prime \prime}$ & 140 & $80-140$ & 72 & 50.18 & 22 & 55.16 \\
\hline 38 & $-32 R 8$ & $37^{\circ} 26^{\prime} 53^{\prime \prime}$ & $122^{\circ} 12^{\prime} 24^{\prime \prime}$ & 201 & $60-200$ & 76 & 55.24 & 21 & 59.38 \\
\hline 39 & $-33 \mathrm{D} 2$ & $37^{\circ} 27^{\prime} 39^{\prime \prime}$ & $122^{\circ} 12^{\prime} 05^{\prime \prime}$ & 207 & $52-198$ & 54 & na & na & na \\
\hline 40 & $-33 \mathrm{D} 5$ & $37^{\circ} 27^{\prime} 30^{\prime \prime}$ & $122^{\circ} 12^{\prime} 00^{\prime \prime}$ & 200 & $65-160$ & 60 & 34.05 & 25 & 36.69 \\
\hline 41 & $-33 D 8$ & $37^{\circ} 27^{\prime} 37^{\prime \prime}$ & $122^{\circ} 12^{\prime} 01^{\prime \prime}$ & 240 & $37-227$ & 54 & 28.00 & 27 & ${ }^{8} 30.32$ \\
\hline 42 & $-33 \mathrm{G} 1$ & $37^{\circ} 27^{\prime} 22^{\prime \prime}$ & $122^{\circ} 11^{\prime} 31^{\prime \prime}$ & 261 & na & 65 & 36.55 & 28 & ${ }^{9} 38.70$ \\
\hline 43 & $-33 \mathrm{~K} 2$ & $37^{\circ} 27^{\prime} 04^{\prime \prime}$ & $122^{\circ} 11^{\prime} 36^{\prime \prime}$ & 450 & na & 76 & 57.12 & 18 & 61.80 \\
\hline 44 & $-33 \mathrm{~K} 3$ & $37^{\circ} 27^{\prime} 09^{\prime \prime}$ & $122^{\circ} 11^{\prime} 29^{\prime \prime}$ & 243 & na & 72 & 54.35 & 18 & ${ }^{10} 60.10$ \\
\hline 45 & $-33 K 6$ & $37^{\circ} 27^{\prime} 11^{\prime \prime}$ & $122^{\circ} 11^{\prime} 40^{\prime \prime}$ & 215 & $90-210$ & 70 & na & na & ${ }^{11} 45.40$ \\
\hline 46 & $-33 \mathrm{~K} 7$ & $37^{\circ} 27^{\prime} 14^{\prime \prime}$ & $122^{\circ} 11^{\prime} 39^{\prime \prime}$ & 195 & 115-195 & 68 & 46.92 & 21 & 52.25 \\
\hline 47 & $-33 \mathrm{M} 3$ & $37^{\circ} 27^{\prime} 07^{\prime \prime}$ & $122^{\circ} 12^{\prime} 06^{\prime \prime}$ & 200 & $80-180$ & 71 & 47.01 & 24 & 52.40 \\
\hline 48 & $-33 \mathrm{M} 4$ & $37^{\circ} 27^{\prime} 14^{\prime \prime}$ & $122^{\circ} 12^{\prime} 02^{\prime \prime}$ & 200 & $40-180$ & 68 & na & na & 1245.34 \\
\hline 49 & $-34 \mathrm{H} 1$ & $37^{\circ} 27^{\prime} 22^{\prime \prime}$ & $122^{\circ} 10^{\prime} 05^{\prime \prime}$ & 310 & $180-270$ & 53 & 35.05 & 18 & 39.65 \\
\hline 50 & $6 \mathrm{~S} / 3 \mathrm{~W}-04 \mathrm{C} 1$ & $37^{\circ} 26^{\prime} 39^{\prime \prime}$ & $122^{\circ} 11^{\prime} 54^{\prime \prime}$ & 195 & $50-190$ & 84 & 63.62 & 21 & 67.92 \\
\hline 51 & $-04 C 6$ & $37^{\circ} 26^{\prime} 44^{\prime \prime}$ & $122^{\circ} 11^{\prime} 45^{\prime \prime}$ & 190 & na & 85 & 61.44 & 24 & 65.12 \\
\hline 52 & $-04 \mathrm{D} 1$ & $37^{\circ} 26^{\prime} 48^{\prime \prime}$ & $122^{\circ} 12^{\prime} 14^{\prime \prime}$ & 202 & $60-160$ & 77 & 51.00 & 26 & 54.94 \\
\hline 53 & $-05 \mathrm{~A} 1$ & $37^{\circ} 26^{\prime} 39^{\prime \prime}$ & $122^{\circ} 12^{\prime} 26^{\prime \prime}$ & 240 & $60-200$ & 84 & 62.67 & 21 & 67.77 \\
\hline 54 & $-05 A 3$ & $37^{\circ} 26^{\prime} 46^{\prime \prime}$ & $122^{\circ} 12^{\prime} 20^{\prime \prime}$ & na & na & 80 & 56.00 & 24 & 60.52 \\
\hline 55 & $-05 B 2$ & $37^{\circ} 26^{\prime} 45^{\prime \prime}$ & $122^{\circ} 12^{\prime} 39^{\prime \prime}$ & 170 & $70-150$ & 86 & 68.15 & 18 & 71.42 \\
\hline 56 & $-05 \mathrm{C} 3$ & $37^{\circ} 26^{\prime} 39^{\prime \prime}$ & $122^{\circ} 12^{\prime} 55^{\prime \prime}$ & 160 & 79-139 & 98 & 37.45 & 61 & ${ }^{13} 54.87$ \\
\hline
\end{tabular}

${ }^{1}$ Well pump believed to be located at depth of about $50 \mathrm{ft}$ from land surface.

${ }^{2}$ Well not assigned an official state/site identification.

${ }^{3}$ Spring 1994-summer 1995.

${ }^{4}$ Total well depth believed to be about $75 \mathrm{ft}$.

${ }^{5}$ Spring 1993-spring 1994 and September 1995.

6 Autumn 1993-spring 1994.

${ }^{7}$ Spring 1993-summer 1994.

${ }^{8}$ April 1993 and summer 1994-summer 1995.

${ }^{9}$ Summer 1994-summer 1995.

${ }^{10}$ Summer 1994-summer 1995.

${ }^{11}$ October 1993-January 1994.

${ }^{12}$ Summer 1993-summer 1994.

${ }^{13}$ Spring 1994-summer 1995. 
Appendix B. Ground-water quality analysis for major ions, boron, and nutrients, in Atherton, California, October 18-22, 1993 $\left[\mu \mathrm{S} / \mathrm{cm}\right.$, microsiemen per centimeter at $25^{\circ} \mathrm{Celsius;}{ }^{\circ} \mathrm{C}$, degrees Celsius; $\mathrm{mg} / \mathrm{L}$, milligram per liter; $\mu \mathrm{g} / \mathrm{L}$, microgram per liter]

\begin{tabular}{|c|c|c|c|c|c|c|c|c|}
\hline $\begin{array}{l}\text { Map no. } \\
\text { (fig. 3) }\end{array}$ & Date & $\begin{array}{c}\text { Specific } \\
\text { conductance } \\
(\mu \mathrm{S} / \mathrm{cm})\end{array}$ & $\begin{array}{c}\text { pH } \\
\text { (standard } \\
\text { units) }\end{array}$ & $\begin{array}{l}\text { Temperature, } \\
\text { water } \\
\left({ }^{\circ} \mathrm{C}\right)\end{array}$ & $\begin{array}{c}\text { Total } \\
\text { hardness } \\
\text { (mg/l as } \\
\mathrm{CaCO}_{3} \text { ) }\end{array}$ & $\begin{array}{l}\text { Calcium, } \\
\text { dissolved } \\
\text { (mg/L) }\end{array}$ & $\begin{array}{l}\text { Magnesium, } \\
\text { dissolved } \\
(\mathrm{mg} / \mathrm{L})\end{array}$ & $\begin{array}{l}\text { Percent } \\
\text { sodium }\end{array}$ \\
\hline 1 & $10-19-93$ & 1,640 & 7.0 & 18.0 & 630 & 160 & 55 & 32 \\
\hline 4 & $10-18-93$ & 1,630 & 7.0 & 18.0 & 670 & 170 & 60 & 27 \\
\hline 5 & $10-19-93$ & 910 & 7.7 & 19.0 & 360 & 110 & 21 & 27 \\
\hline 7 & $10-18-93$ & 1,120 & 7.7 & 20.5 & 290 & 83 & 19 & 48 \\
\hline 13 & $10-18-93$ & 937 & 7.6 & 20.5 & 300 & 82 & 23 & 37 \\
\hline 18 & $10-19-93$ & 1,480 & 7.0 & 17.0 & 610 & 160 & 51 & 25 \\
\hline 19 & $10-19-93$ & 1,300 & 7.2 & 18.0 & 590 & 170 & 39 & 22 \\
\hline 20 & $10-18-93$ & 838 & 7.6 & 19.5 & 320 & 91 & 22 & 28 \\
\hline 21 & $10-20-93$ & 1,120 & 7.4 & 19.0 & 460 & 130 & 34 & 25 \\
\hline 22 & $10-20-93$ & 1,160 & 7.4 & 20.0 & 470 & 130 & 35 & 27 \\
\hline 27 & $10-22-93$ & 1,070 & 7.2 & 17.0 & 430 & 120 & 31 & 28 \\
\hline 29 & $10-21-93$ & 1,260 & 6.8 & 17.5 & 480 & 110 & 49 & 32 \\
\hline 30 & $10-20-93$ & 1,050 & 7.1 & 18.0 & 450 & 120 & 37 & 19 \\
\hline 34 & $10-20-93$ & 1,950 & 7.8 & 19.5 & 600 & 130 & 68 & 42 \\
\hline 37 & $10-21-93$ & 980 & 6.8 & 17.5 & 410 & 110 & 32 & 24 \\
\hline 40 & $10-21-93$ & 1,380 & 7.0 & 17.0 & 590 & 160 & 46 & 20 \\
\hline 45 & $10-22-93$ & 1,190 & 7.5 & 19.0 & 530 & 150 & 37 & 21 \\
\hline 47 & $10-21-93$ & 964 & 7.6 & 18.0 & 400 & 110 & 31 & 20 \\
\hline 50 & $10-20-93$ & 936 & 7.3 & 18.0 & 400 & 110 & 30 & 21 \\
\hline 53 & $10-22-93$ & 1,530 & 6.9 & 18.0 & 420 & 110 & 36 & 44 \\
\hline $\begin{array}{l}\text { Map no. } \\
\text { (flg. 3) }\end{array}$ & Date & $\begin{array}{c}\text { Sodium } \\
\text { absorption- } \\
\text { ratio }\end{array}$ & $\begin{array}{l}\text { Sodium } \\
\text { dissolved } \\
\text { (mg/L) }\end{array}$ & $\begin{array}{c}\text { Potassium, } \\
\text { dissolved } \\
\text { (mg/L) }\end{array}$ & $\begin{array}{c}\text { Bicarbonate } \\
\text { (mg/L as } \\
\left.\mathrm{HCO}_{3}\right)\end{array}$ & $\begin{array}{l}\text { Alkalinity } \\
\text { (mg/L as } \\
\mathrm{CaCO}_{3} \text { ) }\end{array}$ & $\begin{array}{l}\text { Sulfate, } \\
\text { dlssolved } \\
\text { (mg/L) } \\
\end{array}$ & $\begin{array}{l}\text { Chloride, } \\
\text { dissolved, } \\
\text { (mg/L) }\end{array}$ \\
\hline 1 & $10-19-93$ & 2 & 130 & 0.4 & 700 & 574 & 120 & 160 \\
\hline 4 & $10-18-93$ & 2 & 110 & .5 & 669 & 548 & 130 & 130 \\
\hline 5 & $10-19-93$ & 1 & 59 & 1.8 & 398 & 326 & 66 & 68 \\
\hline 7 & $10-18-93$ & 3 & 120 & 2.3 & 303 & 248 & 55 & 160 \\
\hline 13 & $10-18-93$ & 2 & 79 & 2.0 & 303 & 248 & 53 & 120 \\
\hline 18 & $10-19-93$ & 2 & 89 & .8 & 634 & 520 & 91 & 110 \\
\hline 19 & $10-19-93$ & 1 & 72 & 2.2 & 578 & 474 & 86 & 110 \\
\hline 20 & $10-18-93$ & 1 & 57 & 1.8 & 307 & 252 & 55 & 90 \\
\hline 21 & $10-20-93$ & 1 & 68 & 1.9 & 403 & 330 & 62 & 140 \\
\hline 22 & $10-20-93$ & 2 & 77 & 2.0 & 390 & 320 & 67 & 150 \\
\hline 27 & $10-22-93$ & 2 & 75 & .7 & 554 & 454 & 63 & 63 \\
\hline 29 & $10-21-93$ & 2 & 100 & .5 & 583 & 478 & 91 & 82 \\
\hline 30 & $10-20-93$ & 1 & 48 & 1.2 & 473 & 388 & 50 & 92 \\
\hline 34 & $10-20-93$ & 4 & 200 & 1.5 & 290 & 238 & 270 & 330 \\
\hline 37 & $10-21-93$ & 1 & 58 & 1.5 & 407 & 334 & 79 & 75 \\
\hline 40 & $10-21-93$ & 1 & 64 & 1.9 & 529 & 434 & 81 & 150 \\
\hline 45 & $10-22-93$ & 1 & 63 & 2.3 & 586 & 480 & 57 & 95 \\
\hline 47 & $10-21-93$ & 1 & 46 & 1.6 & 383 & 314 & 43 & 100 \\
\hline 50 & $10-20-93$ & 1 & 47 & 1.8 & 425 & 348 & 43 & 62 \\
\hline 53 & $10-22-93$ & 3 & 150 & .9 & 256 & 210 & 190 & 240 \\
\hline
\end{tabular}


Appendix B. Ground-water quality analysis for major ions, boron, and nutrients, in Atherton, California, October 18-22, 1993-Continued

\begin{tabular}{|c|c|c|c|c|c|c|c|}
\hline $\begin{array}{c}\text { Map no. } \\
\text { (fig. 3) }\end{array}$ & Date & $\begin{array}{c}\text { Fluoride, } \\
\text { dissolved } \\
\text { (mg/L) }\end{array}$ & $\begin{array}{c}\text { Silica } \\
\text { dissolved } \\
\text { (mg/L) }\end{array}$ & $\begin{array}{c}\text { Dissolved } \\
\text { solids } \\
\text { (mg/L) }\end{array}$ & $\begin{array}{c}\mathrm{NO}_{2}+\mathrm{NO}_{3}, \\
\text { dlssolved as } \mathrm{N} \\
\text { (mg/L) }\end{array}$ & $\begin{array}{c}\text { Nitrite, } \\
\text { dlssolved as N } \\
\text { (mg/) }\end{array}$ & $\begin{array}{c}\text { Boron, } \\
\text { dlssolved } \\
(\mu g / L)\end{array}$ \\
\hline 1 & $10-19-93$ & 0.3 & 31 & 1,020 & 5.1 & 0.01 & 580 \\
\hline 4 & $10-18-93$ & .3 & 31 & 987 & 5.9 & .01 & 500 \\
\hline 5 & $10-19-93$ & .1 & 29 & 551 & .06 & .01 & 250 \\
\hline 7 & $10-18-93$ & .3 & 28 & 623 & 1.3 & .01 & 780 \\
\hline 13 & $10-18-93$ & .2 & 27 & 540 & 1.1 & .01 & 200 \\
\hline 18 & $10-19-93$ & .3 & 31 & 898 & 12.0 & .01 & 370 \\
\hline 19 & $10-19-93$ & .2 & 32 & 818 & 4.9 & .01 & 330 \\
\hline 20 & $10-18-93$ & .2 & 28 & 496 & .07 & .01 & 200 \\
\hline 21 & $10-20-93$ & .2 & 31 & 671 & 1.3 & .01 & 130 \\
\hline 22 & $10-20-93$ & .3 & 29 & 697 & 3.3 & .01 & 130 \\
\hline 27 & $10-22-93$ & .3 & 32 & 669 & 2.5 & .01 & 200 \\
\hline 29 & $10-21-93$ & .3 & 32 & 778 & 6.0 & .01 & 260 \\
\hline 30 & $10-20-93$ & .2 & 33 & 630 & 3.7 & .01 & 110 \\
\hline 34 & $10-20-93$ & .3 & 31 & 1,170 & .17 & .01 & 150 \\
\hline 37 & $10-21-93$ & .2 & 36 & 619 & 6.1 & .01 & 130 \\
\hline 40 & $10-21-93$ & .2 & 31 & 811 & 3.8 & .01 & 200 \\
\hline 45 & $10-22-93$ & .2 & 28 & 726 & 1.1 & .03 & 240 \\
\hline 47 & $10-21-93$ & .2 & 32 & 566 & 3.2 & .01 & 120 \\
\hline 50 & $10-20-93$ & .2 & 29 & 564 & 7.3 & .01 & 130 \\
\hline 53 & $10-22-93$ & .2 & 36 & 927 & 8.5 & .01 & 180 \\
\hline
\end{tabular}

